\title{
Universal Design to Limit Food Cross-Contamination: Incased Set of Kitchen Utensils with Five Color-Coded Food Chopping Boards and Knifes
}

\begin{abstract}
Diana Starovoytova
School of Engineering, Moi University P. O. Box 3900, Eldoret, Kenya

Abstract

This-study is focused on a-conceptual-design of a-kitchen-appliances/utensils-set, comprising of five-color-coded food-chopping-boards and five-matching-color-coded-knifes, to-reduce cross-contamination at private-homes, aswell-as at food-establishments. Selected-relevant-Patents, as-well-as products, available locally and internationally, were analyzed. The-Joseph-Joseph Index ${ }^{\mathrm{TM}}$ Color-Coded Chopping-Boards set (of four), was chosen as a-point of reference for the-current-design; its-seven-identified-limitations have-directed the-scope of the-current-design. Target-specifications/objectives, of the-set, were formulated from the-document-analysis, while Pair-wiseComparison-Charts were-used, to-rank the-importance of the-objectives, in the-different-levels. The-best-rankeddesign (out of the-four-alternatives made) was chosen, via standard Engineering-Design Weighted-DecisionMatrix (EDWDM) and 'Drop and Re-vote' (D\&R) method. 2D-drawings, of the-best-design-alternative, were created via computer-aided-design (CAD) AutoCAD-software 2018, while 3D-modeling, of the-set and all-itscomponents, was produced by Autodesk-Inventor-Version: 2016 (Build 200138000, 138). Designed-labels (positioned on each-board and each-knife, as-well-as on the-set itself, as an-inclined-panel) were introduced, tocater for the-people with color-blindness (according to-the-fundamental-principles of the-Universal-design), and also to-avoid-confusion (as a-reminder which board is which) for all-users. The-study adopted 'analysis' method of materials-selection. The-main objectives, of the-intended-set, was used as a-guide, in-preliminary-materialsselection. This-concise-study has focused on conceptual-design only; and, hence, it-is further-recommends to: (i) carry-out a-detailed-design; (ii) select a-specific-material (out of the-group, identified by this-study); (iii) choose a-mode of fabrication of the-set; (iv) examine the-possibility of incorporating of anti-microbial-agent(s) and/or coating(s); (v) fabricate the-prototype(s); (vi) conduct explorative-use-ability-trials; and (vii) analyze themarketing-aspect of the-final-set. This-work is potentially-beneficial-to engineering-product-design students and faculty, as-well-as to-households and food-establishments (subject-to successful-implementation).
\end{abstract}

Keywords: Color blindness; Materials selection; Food safety; Joseph Joseph Index ${ }^{\mathrm{TM}}$ Color Coded Chopping Boards set.

DOI: $10.7176 /$ ISDE/10-5-05

Publication date:June $30^{\text {th }} 2019$

\subsection{Introduction.}

1.1. Food-safety and food-contamination.

1.1.1. Food-safety.

FAO \& UN (1999) states, that: "It-is-important to-differentiate between food-safety and food-quality"; Safety refers-to hazards-to human-health in-food, while Quality refers to all-attributes, and, thus, might include safety. In-particular, Food-safety encompasses actions, aimed-at ensuring that all-food is as-safe-as possible (World-Bank, 2000). According-to Velusamy et al. (2010), food-safety is a-global-health-goal, while food-borne-diseases are amajor health-issue, worldwide. The-latter, in-general, can be attributed-by several-factors, such-as: the-nature of food and its-preparation, under-cooking of the-food, dirty-equipments and cutting-surfaces, and the-food-handlersthemselves, among-others.

The-risks to-food-safety, according-to the-World-Bank-report of 2000, fall-into four-broad-categories, namely; (i) microbes, through improper-handling; (ii) parasites, through improper-cooking; (iii) physical-agents, which may-be intentionally, or accidently, added into the-food; and (iv) chemicals, which occur naturally in-food, and those, which are present in-the-environment (World-Bank, 2000).

All-countries share similar-concerns about food-safety-hazards, but the-relative-importance of risks differs with climate, food-eating- and cooking-habits, levels of income, and public-infrastructure. Some-risks are greater, in-developing-countries, due-to poor-sanitation and inadequate-water-supplies (World-Bank, 2000).

\subsubsection{Food-contamination.}

WHO (2008) defines food-contamination as "the introduction or occurrence of a contaminant in food environment which causes food to be unsafe". WHO (1999) developed a-framework, that outlines the-various-sources of foodcontaminations, to-include: food-handlers, flies and pests, polluted-water, dirty-pots and cooking-utensils, domestic-animals, indigenous-micro-flora, infected-food, animals, and human-excreta. Ball et al. (2013) outlines 
the-following-factors to-be the-major-causes of food-contamination: (i) Preparation of food, several-hours priorto consumption; (ii) Insufficient-cooking or reheating; (iii) Cross-contamination; and (iv) Serving of food using dirty-utensils.

This-study is focused of the-food-cross-contamination and its-reduction.

According-to WHO (2008), food-contamination-transfer is dependent on the: (i) surface; (ii) food-type (the-moisture of the-food); (iii) contact-time; and (iv) inoculums-matrix. Epidemiological-data indicate that crosscontamination during-food-preparation in the-home contributes noticeably-to the-occurrence of food-bornediseases (Sampers et al., 2010). To-help-prevent such-occurrences, the-inclusion of a-cross-contamination-model, in-exposure-assessments, would-aid in-the-development and evaluation of interventions, used to-control thespread of pathogenic-bacteria (Sampers et al., 2010).

Figure 1 shows the-simplified model of food-cross-contamination.

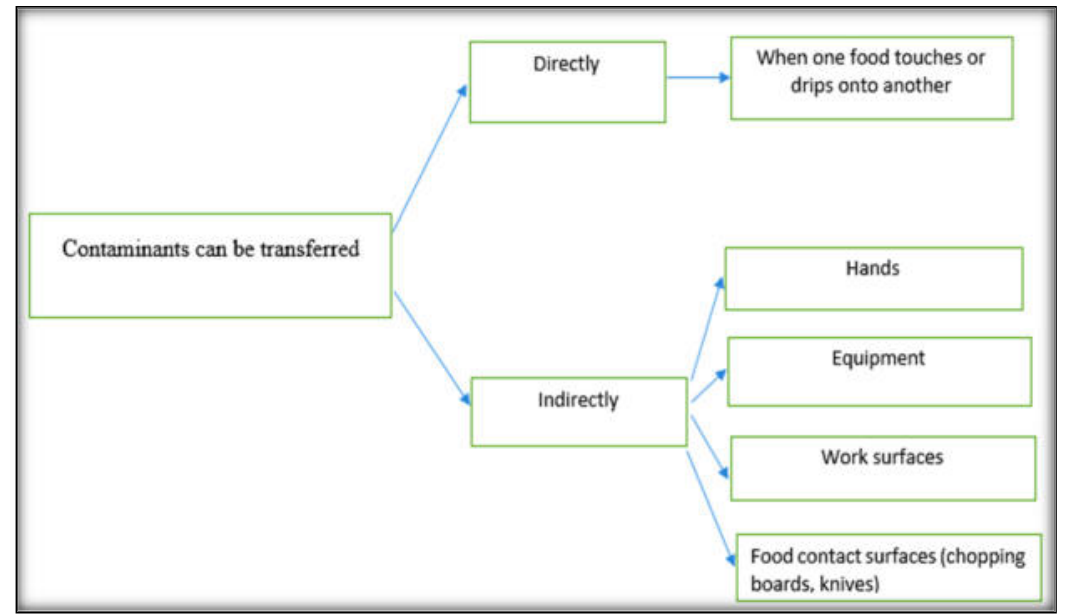

Figure 1: Cross-contamination-channels.

Household, and other-food-establishment-types, have been the-focus of numerous-food-crosscontamination-studies; the-surfaces-studied include: ceramic-tile (Jensen et al., 2013; Dawson et al., 2007; Wendt et al., 1997); stainless-steel (Jensen et al., 2013; Kusumaningrum et al., 2004; Moore et al., 2003; Midelet \& Carpentier, 2002; Wendt et al., 1997); wood (Dawson et al., 2007), glass (Jensen et al., 2013); and plastic (Jensen et al., 2013; Chen et al., 2001; Zhao et al., 1998). Studies, involving transfer from similar-surfaces-to foods havecome-to various-conclusions (Jensen et al., 2013; Dawson et al., 2007). These-differences may be due-to the-range of experimental-procedures, among-published-studies. Differences include: (i) the-times of contact betweensurfaces (Jensen et al., 2013; Dawson et al., 2007; Moore et al., 2003); (ii) the-organisms used (Jensen et al., 2013; Dawson et al., 2007; Moore et al., 2003; Kusumaningrum et al., 2003); (iii) the-foods and contact-surfaces (type and wet/dry condition) used (Miranda \& Schaffner, 2016; Jensen et al., 2013; Dawson et al., 2007; Moore et al., 2003; Kusumaningrum et al., 2003); and (iv) drying-times (Jensen et al., 2013; Dawson et al., 2007; Ryu \& Beuchat, 2005; Donlan, 2002); each of which can result in-different-outcomes. On-the-other-hand, a-research by D'Souza et al. showed that pressure-changes, ranging from 1 to $100 \mathrm{~g} / \mathrm{cm}^{2}$ had no effect on the-contaminationtransfer (D'Souza et al., 2006).

Besides, only limited-data is available to-quantify, precisely, the-food-cross-contamination (Mylius et al., 2007; Nauta et al., 2007). For-example, for Camp. jejuni only data on board-transfer were found (see Luber et al., 2009; Kusumaningrum et al., 2004; Moore et al., 2003), and limited-data on knife-transfer (see Luber et al. 2009). For hand-transfer and hand-washing, only data on Enterobacter aerogenes are present, which is used as surrogateorganism for Salmonella (Montville et al., 2001; Chen et al., 2000).

1.1.3. Food-borne-diseases and their-impacts.

Food-borne-diseases are regarded-as acute-illnesses, associated-with the-recent-consumption of food, having normally a-short-incubation-period, and symptoms, with gastrointestinal-features, including: vomiting, diarrhea, and abdominal-cramps. In-some-cases, there may be neurological and other-symptoms, connected with thealimentary-tract (WHO, 2008). According to Mukhola (2000), WHO regards illness, due-to contaminated-food, as one of the-most-widespread health-problems, in the-contemporary-world.

Although proper-food-handling, preparation, storage, and feeding-practices may prevent many-food- 
borne-diseases, each-year, millions of people become ill, and thousands die, from these-diseases (Kumiko et al., 2009). The-Centers for Disease-Control and Prevention (CDC, 2015; 2014) estimates, that each-year there are more-than 9 million-episodes of food-borne-illness, over 55,000 hospitalizations, and at-least 1,351 deaths, that can be attributed-to foods-consumed, in the-United-States (Scallan et al., 2011), while FSWSG (2008) indicates much-higher-fatality of 3,000 people, while WHO (2008) estimates even-higher-number of deaths $(5,000)$, tooccur each-year, in the-U.S.A., alone. In-particular, during 1998-2008 periods, reporting was made, through theelectronic Food-borne Outbreak-Reporting-System (eFORS), that out of the 7,998 outbreaks, with a-knownetiology, 3,633 (45\%) were caused by viruses; 3,613 (45\%) - by bacteria; $685(5 \%)$ - by chemical and toxic-agents; and $67(1 \%)$ - by parasites (see Gould et al., 2010 for more-details).

The-Health-Canada and the-Public-Health-Agency of Canada also-estimate that every-year, between 11 and 13 million Canadians suffer from illnesses, caused by food-borne-contamination-agents (FSWSG, 2008). In 2005 there were 1,545 incidents of food-poisonings, reported in-Japan, and $86 \%$ of those were caused by bacteria or viruses (WHO, 2014). Besides, Campylobacter jejuni is identified as the-top-five of pathogens, causing mostfood-related-infections, worldwide (Zwietering \& van Asselt, 2005). In-the-Netherlands, for-instance, there are an-estimated 65, 000 campylobacteriosis-cases, per-year (Kemmeren et al., 2006).

Several-devastating-outbreaks of food-borne-diseases, such-as: salmonellosis, entero-haemorrhagic Escherichia coli (EHEC), cholera, hepatitis A, and acute-aflatoxicosis, have occurred in-a-number of Africancountries, relatively-recently. For-example, outbreaks of cholera, in 2004, in 28 countries resulted in 85,807 cases, and 2,221 deaths. In 2005, reports from 30 countries indicated that 33,934 cases were recorded, and 1,161 deaths have occurred. During the 2004, an-outbreak of acute-aflatoxicosis, in-Kenya, reported 317 cases and 125 deaths. Another-outbreak, reported a-further 74 reported-cases and 28 deaths, in 2005 (FAO \& WHO, 2005).

In-Kenya, food-poisoning, or food-borne-illness, is quite-prevalent. A-report by FAO \& WHO (2005) indicates, that in 2004, the-following-incidences were observed, in-Kenya: gastroenteritis ( 722,275 cases), typhoid (643,151 cases), dysentery (600,660 cases), afflatoxin-poisoning (323 cases), brucellosis (198 cases), and cholera (56 cases). One of the-most-devastating water- and food-born-diseases is considered to-be a-cholera, caused by one of the Vibrio cholerae species. Seven-global-pandemics, of this-contagious-disease, have been recorded, during the-last 200-years (Popovic et al., 1993). Over 100 serotypes of Vibrio cholerae exist, but generally thetoxigenic-strains of the-sero-group 01 cause cholera, and possess documented-epidemic-potential. The-mainsymptom of cholera is a-profuse-diarrhoea, resulting-in dehydration, which, if untreated, leads-to death, withinhours. The-most-rapid-growth of $V$. cholerae $\mathrm{Ol}$ occurs in-moist and alkaline-foods. On most-food, $V$. cholerae 01 can survive from 2 to 14 days, better at $5-10^{\circ} \mathrm{C}$ than at $30-31^{\circ} \mathrm{C}$. V. cholerae 01 also-seems to-survive-better on cooked rather-than on raw-food (Kolvin \& Roberts, 1982).

According-to a-resent-report on Kenya, by WHO (2017): "The country experiences cholera outbreaks every year; however, large cyclical epidemics occur approximately every five to seven years and last for two to three years". For-example, from $1^{\text {st }}$ January through $29^{\text {th }}$ November, 2017, 20 of 47 counties (43\%) in-Kenya have reported-cases. As of $29^{\text {th }}$ November, seven-counties (Embu, Garissa, Kirinyaga, Mombasa, Nairobi, Turkana, and Wajir) continue to-have active-cholera-outbreaks. During the-same-period, a-total of 3967 laboratory-confirmed and probable-cases, including 76 deaths (case-fatality-rate $=1.9 \%$ ) were reported by the-Ministry of Health, Kenya to WHO. Of the-cases reported, 596 were laboratory-confirmed.

Up to $70 \%$ of diarrhea-cases, in-developing-countries, is said to-be-caused, by pathogens, transmitted, through-food (Kumiko et al., 2009). In-Kenya, in-particular, approximately $88 \%$ of diarrhea-associated-deaths is attributable-to unsafe-water, inadequate-sanitation, and unsatisfactory-hygiene, during food-preparation and consumption (Abuga et al., 2017). However, according to Gachuki (2012) the-incidences of food-borne-diseases are not easy to-estimate, in-Kenya, as most of them are unreported or under-reported. In-the-same-line, Gould et al. (2013) points-out, that " food-borne-diseases are possibly 300-350 times more-frequent, than what is reported".

Although most-individuals fully-recover, food-borne-illnesses can result in-chronic-health-problems, in $2-3 \%$ of cases. Illnesses, such-as chronic-arthritis, and hemolytic-uremic-syndrome (HUS) leading to kidneyfailure, have long-term-consequences for the-affected-individual, and for the-economy, and the-society, as a-whole. For-example, Health-Canada estimates that the-annual-cost, related to these-illnesses, and related-deaths, is between 12 and 14 billion dollars (FSWSG, 2008).

\subsubsection{Food-born disease-causing-agents.}

Food-born-pathogens cross-contamination, from-surfaces-to-food, can contribute-to food-borne-diseases (Miranda \& Schaffner, 2016). These-diseases are caused by a-variety of etiological-agents, including: (i) Pathogenic-bacteria (e.g., Salmonella, Escherichia coli, or Shigella); (ii) Parasites (e.g., Cyclospora); (iii) Viruses (e.g., Norovirus); (iv) Fungi, protozoa, trematodes, and cestodes group; (v) natural-toxins (e.g., toxin-producingorganisms (i.e., Staphylococcus aureus or Bacillus cereus, and poisonous-plants); (vi) Chemicals (including heavymetals), and (vii) Nematodes, among-others. Comprehensive-directory, of the-examples, of each-of the-listedagents, can be-found in-WHO (2008). 
Moreover, transfer of pathogens, around the-kitchen-environment, has-been-shown in-many- previous domestic-based-studies (see, for-example, Kennedy et al., 2005; Gorman et al., 2002; Hilton \& Austin, 2000).

\subsubsection{Survival-rates and multiplication of food-born-pathogens.}

According-to Kramer et al. (2006), most-gram-positive-bacteria, such-as: Enterococcus spp., (including VRE), Staphylococcus aureus (including MRSA), or Streptococcus pyogenes, survive for months on dry-surfaces. Many gram-negative-species, such-as Acinetobacter spp., Escherichia coli, Klebsiella spp., Pseudomonas aeruginosa, Serratia marcescens, or Shigella spp., can also-survive for months. A-few-others, such-as Bordetella pertussis, Haemophilus influenzae, Proteus vulgaris, or Vibrio cholerae, however, persist only for days. Mycobacteria, including Mycobacterium tuberculosis, and spore-forming-bacteria, including Clostridium difficile, can alsosurvive for months on surfaces. Candida albicans as the-most-important fungal-pathogen can survive up-to 4 months on surfaces. Persistence of other-yeasts, such-as Torulopsis glabrata, was described to-be-similar (5 months) or shorter (Candida parapsilosis 14 days). In-general, gram-negative-bacteria have-been-described topersist longer, than gram-positive-bacteria. Humid-conditions enhanced persistence, for most-types of bacteria, such-as Chlamydia trachomatis, Listeria monocytogenes, Salmonella typhimurium, Pseudomonas aeruginosa, Escherichia coli, or other-relevant-pathogens. Low-temperatures, e.g., $4^{\circ} \mathrm{C}-6^{\circ} \mathrm{C}$, also improved persistence of most-types of bacteria, such Listeria monocytogenes, Salmonella typhimurium, MRSA, corynebacteria, Escherichia coli, Helicobacter pylori, and Neisseria gonorrhoeae, among-others.

Most-viruses, such-as corona, coxsackie, influenza, SARS, or rhino-virus, can persist on surfaces for afew-days. Other-viruses, such-as astro-virus, $H A V$, polio- or rota virus, persist for approximately 2 months. Bloodborne-viruses, such as HBV or HIV, can persist for more than one-week. Herpes-viruses, such-as CMV or HSV type 1 and 2, have-been-shown to-persist from only a-few-hours up-to 7 days. The-most-common-pathogens may well survive, or persist on surfaces, for months, and can, thereby, be a-continuous-source of transmission, if no regular-surface-disinfection is performed (Kramer et al., 2006). A-low-temperature, such-as $4^{\circ} \mathrm{C}-6^{\circ} \mathrm{C}$, was associated-with longer-persistence for most-bacteria, fungi, and viruses. High-humidity (e.g., $>70 \%$ ) was alsoassociated-with longer-persistence for most-bacteria, fungi, and viruses (see Hayden et al., 2006; Noyce et al., 2006; Williams et al., 2006; Wilks et al., 2005; Neely \& Maley, 2000; Maule, 2000).

On-the-other-hand, food-safety is a-scientific-discipline, describing handling, preparation, and storage of food, in-ways, that prevent food-borne-illness (Abuga et al., 2017). According-to the-discipline, bacteria are themost-common-cause of food-borne-outbreaks, since bacteria are microorganisms with high-reproductive-capacity. According to WHO (2014), bacteria multiply by a-method, called 'binary-fission', where one-bacterium becomes 2 , and 2 bacteria become 4, etc. For-example, Vibrio parahemolytica carries-out fission very-quickly, and inconditions, which are good for the-bacteria-growth, it can undergo fission once every-eight-minutes. If eachbacteria splits-in-two, every-eight-minutes, after 3 hours there will be 4,200,000 bacteria and 68,919,470,000 bacteria after 5 hours!

From the-above-information, it can be put-forward, that pathogens do not only survive, for a-long-time, on-the-surfaces, but they are also able to-multiply, rapidly; while conducive-environment, such-as temperature, moisture, $\mathrm{pH}$, and oxygen, can speed-up the-growth of the-pathogens.

\subsubsection{Poor-hygiene-practices, during food-preparation and consumption.}

World-Health-Organization (2008) estimates $40 \%$ of food-borne-disease-cases originate in-the-home, either directly or indirectly, through-avenues, such cutting-board and knives (Gordon, 2018; Bloomfield \& Nath, 2013). Analogous, most-countries report, that between $10 \%$ and $50 \%$ of food-born-diseases, are associated-with privatehome-environment (see Bloomfield \& Nath, 2013; Redmond \& Griffith, 2003; Medeiros et al., 2001), via a-range of contamination-routes (ADPHID, 2017), such-as: cutting-boards; utensils (e.g., knives); counter-tops; surfaces (e.g., refrigerator-handles); food; and food-handler-hands.

According-to van Asselt et al, (2008), up to 87\% of the-sites, where food-born-diseases-outbreaks occur, are associated-with foodstuffs, prepared or consumed in-households, where about $40-60 \%$ of the-cases of foodborne-diseases are caused by inadequate-food and -utensils handling-practices (de Jong et al., 2008), such-as crosscontamination from cutting/chopping-boards (Ravishankar et al., 2010; Luber, 2009; van Asselt et al., 2009; Parry et al., 2005; Kusumaningrum et al., 2004). A-finding from a-resent-study, reported by Abuga et al. (2017), states that consumer-food-hygiene and safety-kitchen-practices were as-low-as $42.9 \%$. Additionally, failure to-associate the-home as a-potential-location to-acquire food-borne-diseases may be a-serious-barrier, for implementation of safe-food-handling-practices (Abuga et al., 2017).

Surface-cross-contamination (for-example via cutting/chopping boards) is the- $6^{\text {th }}$ most-commoncontributing-factor (out of 32) for food-borne-diseases (CDC, 2013; Gould et al., 2013; 2010). The-next-subsection introduces this-food-contamination-route.

Cooking-utensils, including cutting-boards and knifes, washed in-contaminated-water, or food, contaminated, during or after preparation, e.g., moist-foods, contaminated, during or after cooking or preparation, 
and allowed to-remain, at room-temperature, for several-hours, provide an-excellent-environment for the-growth of pathogens, e.g., Vibrio-cholerae (World-Health-Organization, 2008). It-is well-established that a-highpercentage of food-borne-illness is caused by failure of consumers to-prepare food in a-hygienic-manner. Indeed, a-common-practice in-households, is to-use the-same-kitchen-equipment and surfaces, for both; raw-meat and fresh-produce (Gkana et al., 2016).

Microorganisms, attached-to processing-equipment and surfaces, may escape cleaning and sanitizingprocedures, and proceed to-contaminate processed-product. Pathogens, originating with raw-products can attachto food-preparation-surfaces, which, if not adequately-cleaned, before reuse, can serve to-re-contaminate cookedfoods (Frank, 2001). Figure 2 shows an-example of indirect-cross-contamination, where the-same-board and knife were used for raw-meat and for raw-vegetables (served as salad).

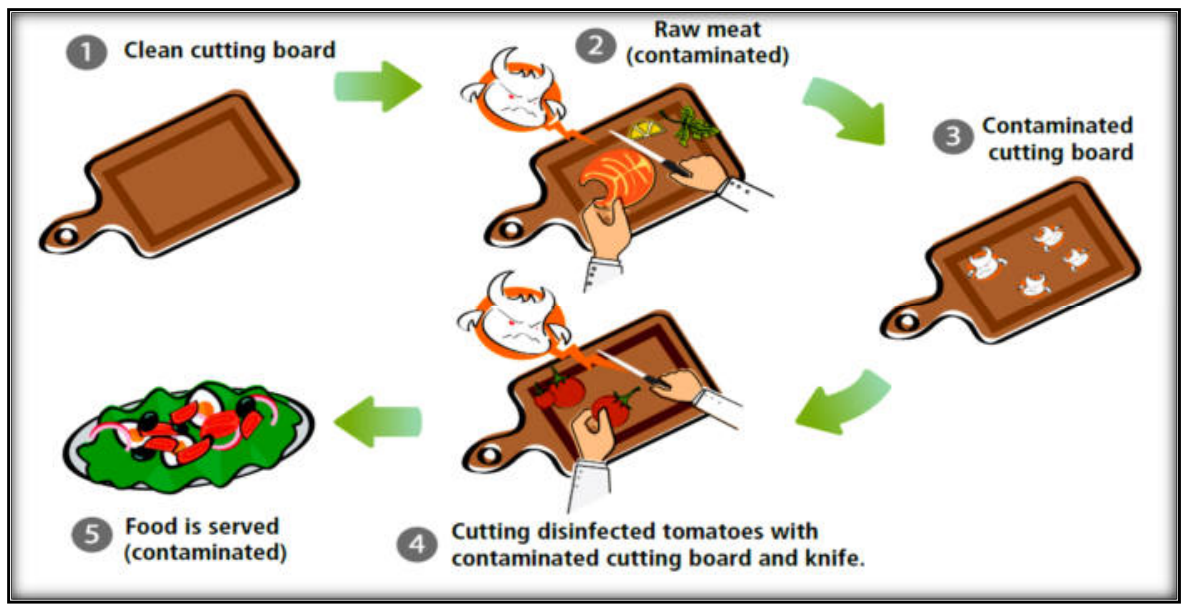

Figure 2: Example of cross-contamination (FAO, 2017).

Cleaning with cold-water and dish-soap, followed by vigorous-scrubbing and rinsing, practices commonly-followed in-household-kitchens, to-clean cutting-boards, may reduce, but not eliminate the-risk of exposure-to the-pathogens (Soares et al., 2012). Hypochlorite-disinfection, of cutting-board-surfaces, is considered-as the-safest and most-efficient-method (Soares et al., 2012), however many, if not all, households, are basically not aware of the-dangers of inadequate-cleaning and food-cross-contamination. When utensils were not cleaned properly, after they were used, the-transfer-rate was $1.25 \%$ from poultry to plastic-board-surface and $45.62 \%$ from plastic and knives to lettuce.

From the-common-methods, used in-cleaning of surfaces, at homes, studies have-shown that water and soap, alone, are not enough, to-ensure de-contamination (Barker et al., 2003; Cogan et al., 2002; 1999; Scott \& Bloomfield, 1990; 1993). To-eliminate the-cross-contamination-route, it-is important to-use separate-surfaces, or to-properly wash the-surfaces, during the-preparation of raw- and cooked-foods, or ready-to-eat-foods (Sampers et al., 2010; Cogan et al., 1999); therefore, in-the-context of this-study, separate chopping-boards, for raw and for cooked-food, are preferable.

\subsection{Research-purpose and selected-relevant-issues.}

\subsection{Research-purpose.}

Poor-hygiene, during preparation and/or consumption of food, in-conjunction-with the-ability of food-bornepathogens to-survive (for a-long-time), and also to-multiply, rapidly, can-lead-to food-cross-contamination. Foodcross-contamination, in-turn, can-lead-to food-born-diseases, resulting in-some-cases, in: (i) severe-sickness, or even death (either immediately, or shortly, after food-consumption), or (ii) in-increased-risk of chronic-diseases (e.g., Guillan-Barre-syndrome, or rheumatoid-arthritis (CAST)).

Food-safety-issues are receiving growing-attention, worldwide, due-to ever-increasing-incidence of food-borne-diseases and their-negative-impacts on the-public-health, economy, and on the-society, at large. Moreover, Luber (2009) points-out that: "There is a focus in many countries to reduce the level of human illness from food-borne pathogens". In-the-same-spirit, this-study is focused on a-conceptual-design of a-kitchenutensils-set of color-coded chopping-boards and knifes, to-reduce food-cross-contamination at private-homes, aswell-as at food-establishments. Universal-design-approach was applied, to-design a-food-chopping-boards-set, with particular-emphasis on the-people with color-blindness-condition; the-next sub-sections provide thebackground-details. 


\subsubsection{Selected-relevant-issues.}

1.2.2.1. Chopping-boards and materials, used in their-fabrication.

A-cutting, or chopping-board, is a-durable flat-board, on which to-place a-product/material, for cutting. Thekitchen-cutting-board is commonly used in-preparing-food, and it-is also-called food-chopping or food-cuttingboard, is an-indispensable kitchen-utensil. Such-boards are often made-of different-materials (see selectedexamples in Figure 3), and come in-various-shapes and sizes.

With-regard-to materials, stainless-steel has often-been-considered the-optimal-material-choice for commercial-food-preparation-surfaces, because of its-resistance-to corrosion and chemical-degradation, mechanical-strength, and ease of cleaning (Wilks et al., 2006), although stainless-steel may have higher-bacterialtransfer-rates than other-surfaces (Wilks et al., 2005; Robine et al., 2002). A-study by Soares et al. evaluated fourtypes of materials, used-as cutting-surfaces, for food-handling: pine-wood; triclosan-treated- plastic; temperedglass, and stainless-steel. Among the-surfaces analyzed, wood was considered to-be the-most-difficult to-clean, while stainless-steel was the-easiest (Soares et al., 2012).

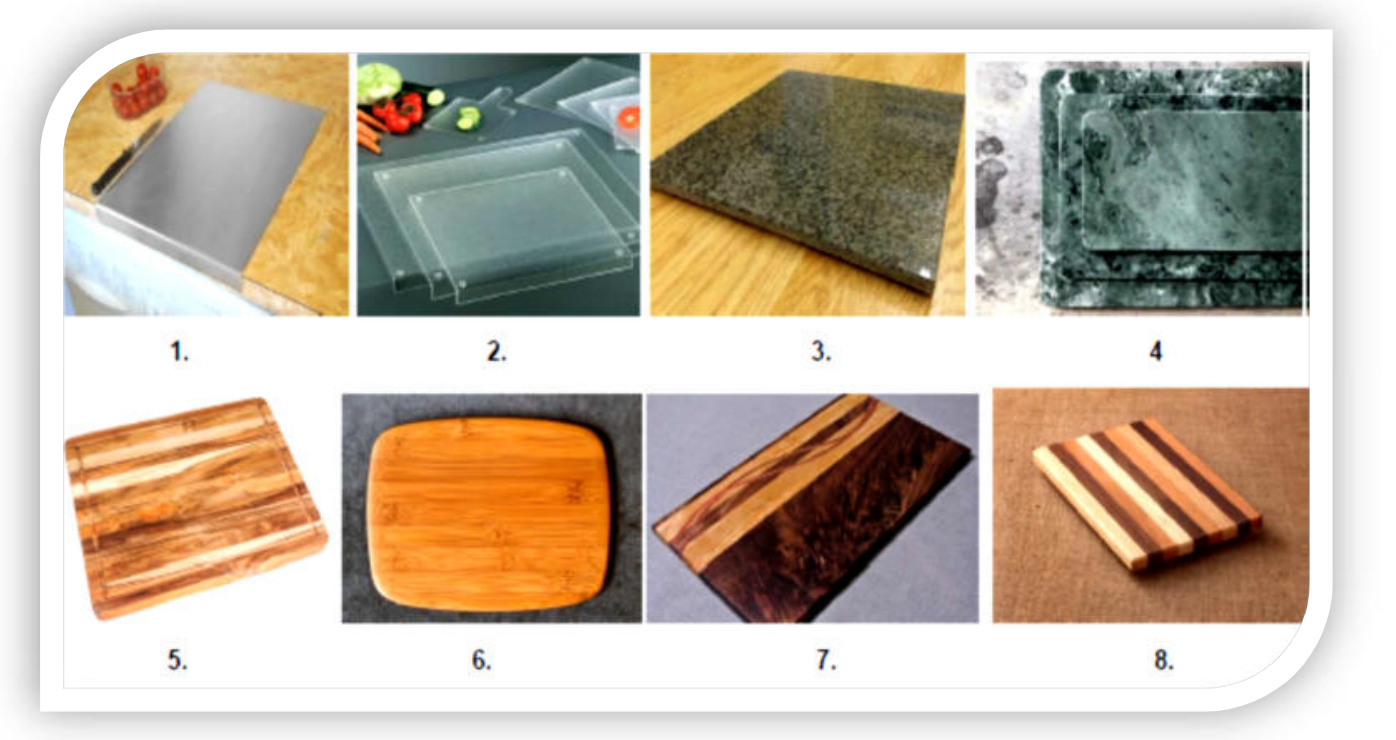

Figure 3: Selected-examples of the-Materials used for chopping-boards.

Keys: 1 - Stainless-steel; 2 - Acrylic; 3 - Granite; 4 - Marble; 5 - Teak; 6 - Bamboo; 7 - Walnut; 8 - Acacia.

In-particular:

(i) Wood is, somewhat, self-healing; shallow-cuts in-the-wood will close-up, on-their-own. Wood also has natural-anti-septic-properties. On-the-other-hand, wood is intrinsically-porous, which allows food-juices and bacteria, to-penetrate the-body of the-wood; the-moisture is drawn inside, in by-the-capillary-action, until there is no more free-fluid on the-surface, at which-point immigration ceases. Bacteria, in the-wood-pores, are not killed instantly, but neither do they return to the-surface (Cliver, 2006; Abrishami et al., 1994). Hard-woods, with tightlygrained-wood and small-pores, are best for wooden-cutting-boards, which help to-reduce absorption of liquid and dirt, into-the-surface. There are different-types/species of wood, which are used for cutting-boards (Aviat et al., 2016; Xi et al. 2013; Milling et al., 2013), for-example:

Acacia cutting-board is often-labeled as the-top-choice for this-kitchen-item; usual-maintenance (oiling), however, is required, to-prevent them from splitting. Acacia is a-highly-sustainable-wood; it has the-appeal of bamboo, but without the-need for international-export.

Walnut cutting-board is the-most-expensive of the-wood-cutting-boards, walnut is a-strong and durablematerial, however it needs maintenance with oil, regularly, otherwise, they can develop very-deep-cracks, making it unhygienic.

Teak cutting-board; Teak, a-tropical-wood, contains tecto-quinones-components of natural-oily-resins, which repel moisture, fungi, warping, rot, and microbes. Teak is also-known for being a-very-durable and waterresistant-form of wood, and for this-reason, it-is a-popular-choice for cutting-boards. Although little-pricy, dueto-its-density, there is minimal-scarring and scratching done, to-it, when used for food-chopping. Besides, teakcutting-board does not require oiling; Teak-wood's tight-grains and natural-coloration make it a-highly-attractive cutting-board-material, both; for aesthetic and durability-purposes. It-is important to-note, however, that there are 
cutting-boards, made from African-Teak or Rhodesian-Teak, which despite the-name, are not made from thesame-species of wood.

Cherry cutting-board has softer-texture, which, on-one-hand, will be helpful in-protecting knives from damage, but it may also-cause more-damage to the-wood, itself. These-boards should never be submerged inwater, or placed in a-dishwasher, just like the-other-wood-varieties. Another-issue is that the-board should be atleast 2 inches, in-thickness, as it can crack easily; regular oiling, proper-washing, and disinfection are needed.

(ii) Bamboo, although commonly-listed under 'wood', strictly-speaking is not a-wood; thedistinguishing-features is that bamboo grows very-fast, while wood not, also these-materials have fundamentallydifferent internal-structure. Bamboo-cutting-boards are considered to-be-naturally-anti-microbial; they can be produced, from multiple-pieces, by lamination. Bamboo has long been a-popular-alternative for wood, in-manyareas, not just with cutting-boards. The-biggest-concern, however, is the-sustainability of the-material. Compared to most-woods, bamboo has a-very-fast re-growth-rate, making it ideal for a-range of products. As most-bamboo is sourced in-China, there is an-issue of questionable-labor-practices, and the-energy-spent, to-transport theproduct, cancelling-out the-sustainable-factor. In-terms of cutting-board-quality, bamboo will require somemaintenance, as it can be quite-hard to-the-touch, and is prone-to splitting and cracking.

(iii) Plastic-boards are usually-called PE (polyethylene) cutting-boards, or HDPE (high-densitypolyethylene-plastic), can be made from injection-molded-plastic, or from an-extrusion-line. Polyethylene-cuttingboards have-been-around, for many-years; and proven to-be the-cheapest and effective-types. Most-HDPE-boards are specifically-designed not to-dull the-edge of a-knife. High-density-polyethylene, which is the-most-used in commercial-applications, has been shown to-delaminate, in-response-to knife-scarring (Gkana et al., 2016; Cliver, 2006).

(iv) Marble cutting-boards are known for being one of the-most-hygienic-forms, due-to their-non-porousnature, and ease of cleaning; however, they can do some-damage to the-knives, because of their-tough-surface.

(v) Granite is another visually-pleasing-material-choice for cutting-boards, however such a-board will dull the-knives, and it can be noisy, during food-chopping.

(vi) Maple cutting-board is considered to-be the-most-expensive, on-the-other-hand it will not damage the-knifes, and will help to-prolong its-life significantly. Cleaning a-maple-cutting-board is relatively-simple, and is it non-porous-material, hence fewer-bacteria and less-water can seep through.

(vii) Stainless-steel cutting-boards are not as-common-as the-previously-mentioned-types. Steel-boards are durable and easy to-clean; they do not warp or swell, like some-wood varieties can, and there is no need to-oil them, or perform any-other-maintenance. However, these-boards can damage the-knives significantly and also cause them to-slip, on the-surface, during use. Besides, the-sound of a-knife, against stainless-steel, particularly when chopping quickly, is not pleasant.

(viii) Acrylic cutting-board is cheap and effective, it-is probably be the-second-choice, after polyethene; such a-board can be submerged in-water, or even washed in-the-dishwasher, hence, it-is very-easy to-maintain, however, it should-be sanitized, and replaced every 12 months; making it an-expensive-option.

- $\quad$ (ix) Rubber boars are as-expensive-as well-made-wooden-boards, and in-addition they do smell. They can withstand chemical-disinfectants, and they are very-heavy for their-size, so they tend not to-slip. Besides, they exhibit self-healing-properties.

(x) Like-rubber, silicone is soft on the-knife-blade, while being just as self-healing and anti-bacterial, aswood. Silicone is also heat-resistant, and lacks the-rubbery-smell of rubber-boards, but it-is expensive.

(xi) Glass cutting-boards are easily-cleaned and they are more-hygienic, however, they can damage knives, harsh-noises are produced, while in-operation, and due-to their-slick and hard-surface, a-knife can easilyslip, while cutting, and cause a-potential-hazard in-the-kitchen. Also glass-board can be easily broken, especially during washing. In-general, glass-cutting-boards are likely-going-to-do more-harm than good.

Numerous-materials can be used, to-produce chopping-boards; each has its-advantages and limitations. For-example, wood, in-general, is said, to-dull knives, less-than plastic, and plastic is seen as-less-porous, than wood (Cliver, 2006); the-wooden-boards, however, should be-regularly oiled, by edible-mineral-oil, to-avoid warping and splitting. Besides, wooden-cutting-boards do not get cuts, as-deep-as plastic. This means the-bacteria cannot become trapped, and will dry-out, eventually. The USDA's Food-News for Consumers recommended strongly that plastic, not wooden, cutting-boards be used in consumers' kitchens. However, a-study by Ak et al. (1994), indicates, that wood had some-sort of antibacterial-effect, which was not found in-plastic.

\subsubsection{Universal-design concept.}

Universal-Design (UD) means the-design of products, environments, programs, and services, to-be-usable by allpeople, to the-greatest-extent-possible, without the-need for adaptation or specialized-design (Vanderheiden, 1997). Seventeen-percent of the-U.S.A.-population has some-form of disability (ADA, 2010; Erickson \& Lee, 2003), numbers are similar, worldwide; besides, probability of people developing a-disability increases-with-age. 
As the-population of people with-disabilities grows, so does the-ethical and economic-pressure, to-provide that population with products, which offer services and value. Nevertheless, many-product-designers and companies are unfamiliar-with-approaches to applying UD (a-term, commonly used to-describe goods and services, which are usable both; by persons with-a-disability and by typical-users (McAdams \& Kostovich, 2011)). Universaldesign is an-active-research-area; nevertheless, formal-methods for the-design are limited in-scope (Danford, 2003; Preiser \& Ostroff (Eds.), 2001; Bowe, 2000). UD is used interchangeably-with Inclusive design (the-term, which mainly-used in the-United-Kingdom (Goodman et al., 2006)), meaning that the-design can be used, equally-well, by people of any-ability: in-other-words, it does not discriminate against users, based on their-ability. In-addition, each of the-Trans-generational, Rehabilitation-design, and Adaptable-design, do share common-elements with UD (Erlandson, 2008; Connell, 1997; Hewer, 1995; Peloquin, 1994). condition.

This-study applies UD-concepts and principles, with particular-emphasis on people with color-blindness-

\subsubsection{Color-blindness-condition.}

Color-blindness, also-known-as color-vision-deficiency, is the-decreased-ability to-see color, or to-differentiate colors (to a-certain-degree or completely) (NEI, 2015; Gordon, 1998). Color-blindness does not mean, however, that a-person can only see black and white. Two major-types of color-blindness are: (i) difficulty distinguishing between red and green; and (ii) difficulty distinguishing between blue and yellow. Based on clinical-appearance, color-blindness may be described-as total or partial; while total-color-blindness is much-less-common, than partial-color-blindness (Hoffman, 2008; Spring et al., 2007; Neitz, 2007).

According-to Blom (2009); Shevell (2003); and Stiles \& Wyszecki (2000), total-color-blindness ('monochromacy') is a-very-rare-condition, in-which, people only see different-tones and brightness-levels, with no color, at-all. Although the-term may refer-to acquired-disorders, such-as cerebral-achromatopsia, also-knownas color-agnosia, it typically-refers-to as congenital-color-vision-disorders (i.e., more frequently rodmonochromacy, and less-frequently cone-monochromacy) (EIZO, 2006).

- The-various-types and characteristics of partial-color-blindness (Wong, 2011; Simunovic, 2010; McIntyre, 2002) are: (i) Anomalous-Trichromacy (a-mild-shift in-the-sensitivity of the-cones); (ii) Protanomaly (shades of red appear weaker in-depth and brightness); (iii) Deuteranomaly (shades of green appear weaker); (iv) Tritanomaly (a-very-rare-condition, in-which shades of blue appear weaker); (v) Dichromacy (severe-deficiency or complete-absence of one of the-types of cones); (vi) Protanopia (shades of red are greatlyreduced in-depth and brightness, if they can be seen, at-all); (vii) Deuteranopia (shades of green are greatlyreduced in-depth and brightness, if they can be seen, at-all); and (viii) Tritanopia (a very-rare-condition, in-which shades of blue are greatly-reduced in-depth and brightness, if they can be seen, at-all).

Color-blindness affects a-large-number of individuals, with protanopia (red-deficient: L-cone absent) and deuteranopia (green-deficient: M-cone absent) being the-most-common-types. In-individuals, with NorthernEuropean-ancestry, as-many-as $8 \%$ of men, and $0.4 \%$ of women, experience congenital-color-deficiency (Chan et al., 2014). Likewise, according-to the Howard Hughes Medical Institute, in the-United-States, about $7 \%$ of the male-population, or about 10.5 million men; and $0.4 \%$ of the-female-population either cannot distinguish red from green, or see red and green, differently from how others do (HHMI, 2006). Color-blindness or, color-visiondeficiency, also affects about 2.7 million-people in-Britain. In-Australia, around $8.0 \%$ of the-male-population is color-blind, compared-to around $0.4 \%$ of the female-population. The-ability to-see color also decreases in old-age.

Being color-blind may make people ineligible for certain-jobs, in-several-countries. This may include being a-pilot, train-driver, traffic-police-officer, and working in-the-armed-forces (NEI, 2015; Wong, 2011). Regardless of the-types, rights of the-color-blind-people have been protected, in-some-states; for-example, according-to the-Decree, issued by president of a-republic, ratifying Legislative-Decree No. 198, of June 13, which approved the Inter-American-Convention AG/RES. 1608, “A Brazilian court ruled that people with color blindness are protected by the Inter-American-Convention on the-Elimination of All-Forms of Discrimination, against Person-with-Disabilities", e.g., the-carriers of color-blindness have a-right of access-to wider-knowledge, or thefull-enjoyment of their-human-condition. In-the-United-States, however, under federal anti-discrimination-laws, such-as "the-Americans with Disabilities Act", color-vision-deficiencies have not yet been found to-constitute adisability, that triggers protection from workplace-discrimination (Larson, 2016; Zhang, 2014).

This-study assumes that color-blindness is a-sort of a-disability; universal-design-approach, to-be-used, to-consider the-condition, by incorporating easy-recognizable-symbols, since colors of the-chopping-boards and cutting-knifes, cannot be distinguished, by the-people with color-blindness.

\subsection{Materials and Methods.}

The-aim of this-research was to-design a-cost-effective, easy-producible, user-friendly, and reliable kitchenutensils-set, that can-be-used to-reduce food-cross-contamination. The-design followed steps of the-fundamental Engineering-Product-Design (see Starovoytova, 2019a; b; 2018); Figure 4 shows the-chronological-steps, 
performed during this-study.

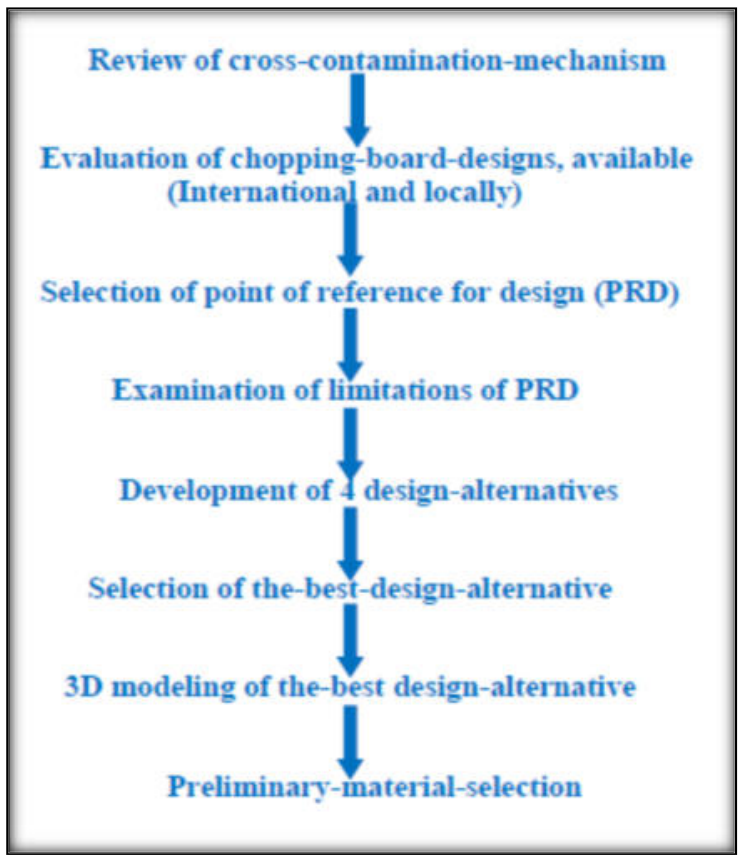

In-particular:

Figure 4: The-chronological-steps, performed during this-study.

Review of cross-contamination-mechanism was done by the-examination of the-available-publishedliterature on the-subject-matter.

Evaluation of chopping-boards designs was conducted by the-desk-study-approach and by nonparticipant-observation. Selected-relevant-patents, as-well-as similar-products, available locally and internationally, were analyzed. In-particular, a-non-participant-observation, across the-various-localsupermarkets, within the-locality of Eldoret-town, Uasin-Gishu-county, and online market-platforms, such-as Jumia and Kilimall, were conducted, to-determine the-availability of chopping-board-sets; Inclusion of knives in the-sets; availability of labels; and different-materials, used in-their-fabrication, among-other-issues.

Selection of PRD was done via comparative-analysis of the-results, obtained from the-previous-step, by identification of the-most-advanced-set (at the-time of the-study), and most-suitable (for this-unfunded-study) design.

Examination of limitations of $P R D$ was done by the-critical-inspection of the-PRD, as-well-as from theavailable-reviews, expressed, by some-users of the-set, at the-official-cite of the-product (see, for-example: https://www.josephjoseph.com/en-rw/index).

Development of four-design-alternatives, were done by the-individual-design-team-members; the-endresult is four-hand-sketches. Besides, some-preliminary-calculations were done, at the-same-time, which mightbe-required to-substantiate ideas and to-establish approximate-sizes.

Selection of the-best-design-alternative; This-study used a-standard Engineering-Design WeightedDecision-Matrix (EDWDM), to-select the-best design-alternative. In-addition, analogous-to Starovoytova (2019 a; b) and Starovoytova \& Namango (2016), to-confirm the-choice, additional-method, of selection of best-designalternative, was used, namely 'D \& R-method'.

2D-drawing, of the-best-design-alternative, was created via computer-aided-design (CAD) AutoCADsoftware, while Autodesk-Inventor-Version: 2016 (Build 200138000, 138) was used for 3D- modeling.

Preliminary-materials-selection; Materials-selection plays an-essential-role in the-product-designprocess (Doordan, 2003), where 4-elements (function, shape, materials, and manufacturing-processes) do interact. Ashby \& Johnson (2003; 2002) identify four-materials-selection-methods: (i) 'Analysis'; (ii) 'Synthesis'; (iii) 'Similarity'; and (iv) 'Inspiration' method. This-study adopted the 'analysis' method, where a-list of productrequirements is translated-into-material-objectives and constraints. The-main objectives, of the-intended-set, was used as a-guide, in-materials-selection. Besides, the-study adopted the-interaction of function, materials, shape, and manufacturing-processes, from Asbhy (1999), and the-interaction of use, function, materials, and shape, from Roozenburg \& Eekels (1995). 


\section{Results.}

3.1. Examination of available-designs.

A-number of relevant-International-patents (developed by individuals, as-well-as design-companies) were

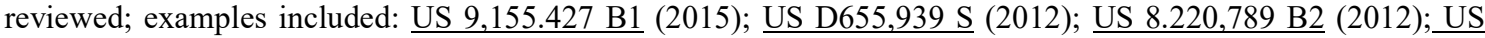
D638,265 S 5 (2011); US 8,070,148 B2 (2011); US 7,681,871 B2 (2010); US14814 A1 (2010); US 200723 A1 8 (2009); US 0146353 A1 (2009); US 0080487 A1 (2007); US 0001359 A1 (2007); US 19221 A1 (2004); US $0046301 \mathrm{~A} 1$ (2004); and US $0195763 \mathrm{Al}$ (2002).

Figure 5 shows selected-examples of different-food-chopping-boards, available in the-localsupermarkets, while Figure 6 demonstrates the-array of products, available on-line.

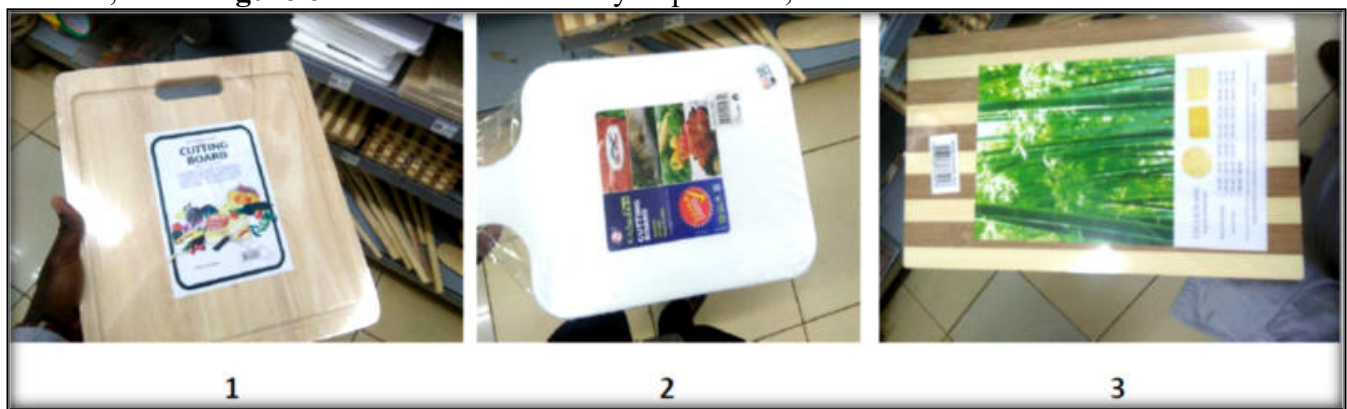

Figure 5: Most-common food-cutting-boards, available at-selected-local-supermarkets. Keys: 1 - wooden; 2 - plastic; 3 - bamboo.

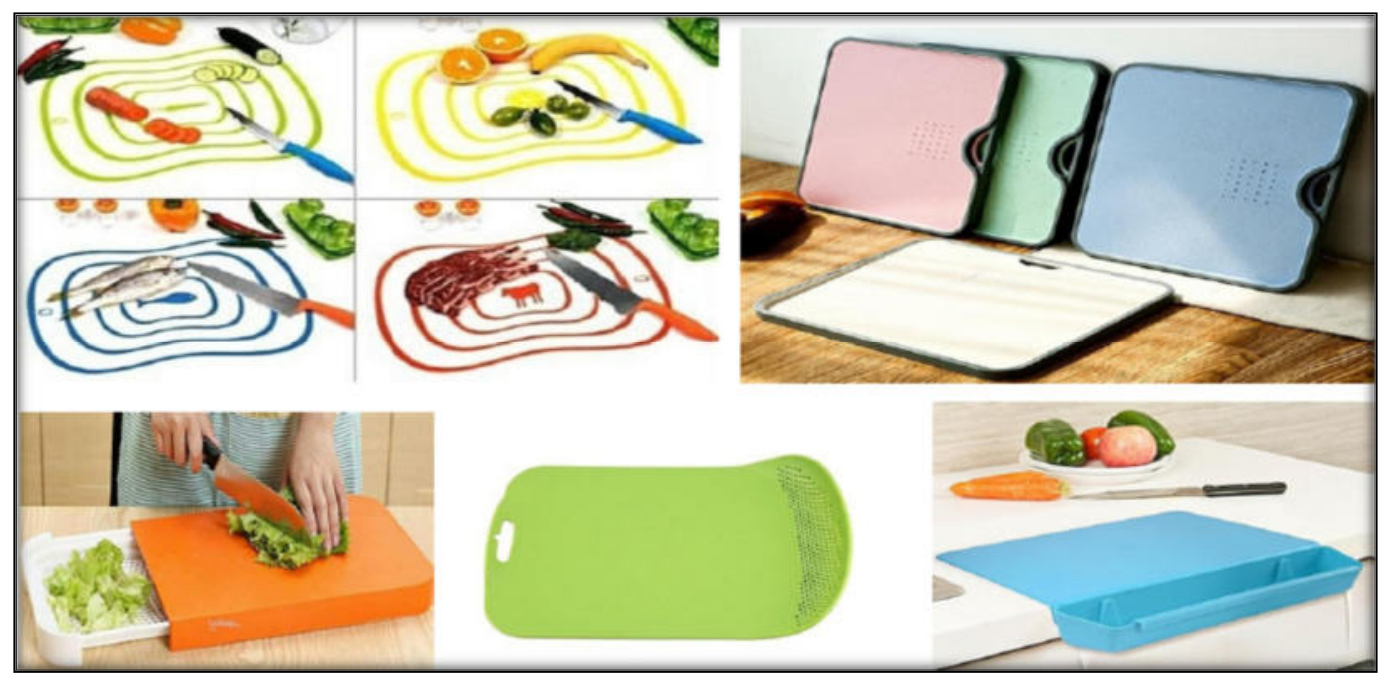

Figure 6: Selected-examples of boards, available for purchase, on-line.

Keys: Upper-row (Left - "Ultra-Thin Fruit Vegetable Chopping-Board Anti-Bacteria Mat Kitchen Tool' (set of 4); Right - 'Wheat-Straw Cutting-Board Gourmet-Chopping with Grinding-Garlic-Tool' (set of 4).

Lower-row (Left - '2 In 1 Creative Foldable Cutting Board with Storage Basket Box for Cooking Tool'; Middle - 'Multifunctional-Drainage-Plastic Chopping-Board'; Right- 'Expandable Chopping-Board').

The-assessment revealed, that: (i) none of the-patents, examined, have featured a-complete-set of colorcoded boards and knifes; (ii) Local-supermarkets, mostly-offered individual-food-chopping-boards (no sets), besides, none had knife-provision; and (iii) Selected-products, available on-line, were pricy, especially for people, in-developing-countries, like Kenya.

3.2. Point of Reference for the-design (PRD), and its-limitations.

Following critical-assessment of available-designs, this-study has chosen Joseph Joseph Index ${ }^{\mathrm{TM}}$ Color Coded Chopping Boards set, as a-point of reference for the-current-design (due to its-uniqueness and appropriateness, toprevent/limit food-cross-contamination. Joseph Joseph Index ${ }^{\mathrm{TM}}$ Color Coded Chopping Boards set, designed by 
Damian Evans, and since its-launch, in 2008, has been a-worldwide-best-seller (at USD 50); Figure 7 shows thePRD.

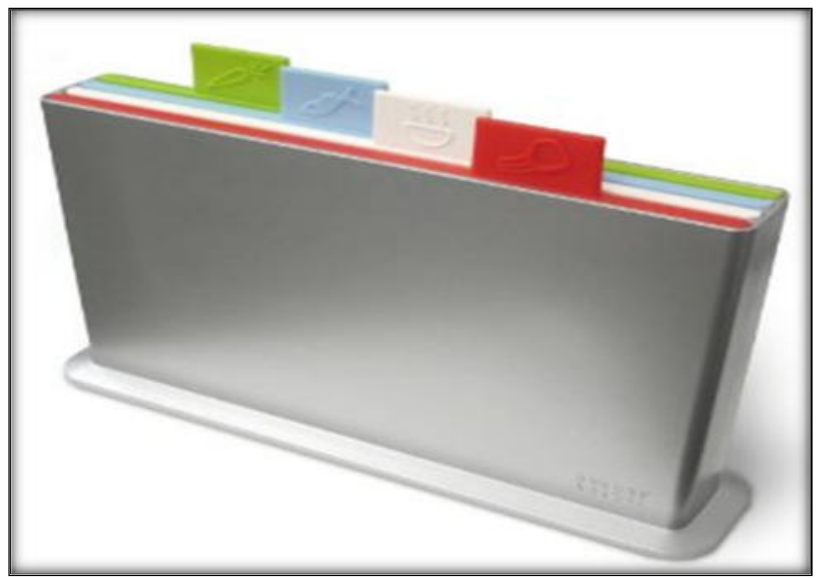

Figure 7: Joseph Joseph Index ${ }^{\mathrm{TM}}$ Color Coded Chopping Boards (set of 4)

Keys: Red - for raw-meats; White - cooked-food; Blue - raw-sea-products;

Green - raw vegetables and fruits.

Figure 7 shows contemporary ABS-storage-case with a-non-slip-base; Boards are stored in-staggeredorder, for visual-ease; Illustrated-tabs/labels provide at-a-glance-reminder, which board is which. Besides, theoperational-manual indicates that, boards are dishwasher-safe.

\subsection{Identified-limitations of the-PRD.}

Several-limitations of the-Joseph-Joseph Index ${ }^{\mathrm{TM}}$ Color-Coded Chopping-Boards (set of four) were identified (by the-physical-observations and from the-product-users-review-blog), and in-particular: (1) the-boards, inside thecasing, are touching each-other, hence, there could be-cross-contamination from one-board to the-neighboring one(s); (2) no drainage-perforations, at the-bottom of the-set, which could lead-to moisture-accumulation, within the-set; (3) no knife, or knifes, included in the-set; (4) protruding-labels tend to-wear-out and become less-visible (as they are used to-get the-boards out of the-casing), hence, losing its-primary-function; (5) according to Ergonomic-design-principles, pinch-grip, used to-get the-boards from the-casing, is much-weaker than the-powergrip (see Starovoytova, 2018), making the-set un-agronomical; (6) There are no board-handles, hence it-is ratherdifficult to-remove individual-boards, from the-casing; and (7) no provision for a-separate-board, specifically for raw-poultry-meats (according to the-Oxford-Dictionary (2018), poultry is the-inclusive-term for chicken, turkey, and duck-meat, as-well-as pheasants, and other-less-available-fowl).

\subsection{Generation of the-design-alternatives.}

This-study is based on the-major premise, that according-to Gkana et al. (2016): "Separate-cutting-boards and knives, should-be-used, for processing raw-meat and preparing ready-to-eat-foods, in-order-to-enhance foodsafety". In-particular, the-current-design is to-address the-identified-above-limitations, by incorporating: (i) separation-plates, between the-boards, inside the-casing; (ii) perforations, within the-removable-bottom of thecasing; (iii) five-colour-coded-knifes, matching colours of each-of the-five-boards; (iv) a-permanent-labels (engraved) on the-boards, knifes, and the-set-casing; and (v) ergonomically-designed-handle for the-board. Where, Separation-plates (vertical-plates, running-through opposite-sides of the-casing, whereby on one-side they cover the-whole-surface, while on the-other-side they cover halfway, with the-side-left open); Perforations (a-series of small-holes, which cover the-whole-bottom-surface of the-casing); Basement (a-separate-block with acompartment for holding draining-water, which can be attached, or detached, from the-main-casing-interface); Labels (well-embossed-symbols on a-slanted-surface on one-side of the-casing, and on every board and knife); Board withdrawal ( the-boards are laid in-such a-way, that the-handles protrude the-outside-surface, of one-side of the-casing, and their-withdrawal is in-a-horizontal-manner); and Knife-inclusion (the-knives are placed incompartment-block, within the-casing, which has small-open-spaces, upon which the-cutting-blades of the-knives can be inserted).

Several-other-issues were also-taken into-account, during the-design-stage, of this-study. First, it was considered, that any-device usually comprises of various-parts. The-utilitarian or functional-part is the-one that truly-performs basic-task, which prompts the-execution of the-segment. The-non-functional-part does not have real-work in-segment-presence, but rather it needs to-do-with support, spreads, examination, and aesthetical-worth, 
and therefore, the-number of non-functional-parts should-be-reduced, to-cut the-cost (Juvinall \& Marshek, 2012; Budynas-Nisbet, 2008).

Besides, the-designed-set, should be: (i) manufacture-able/easy-producible (using locally-availableequipment and expertise; and being able to-be-easily and effectively-colored, in five-distinct-colors); (ii) costeffective; (iii) soft; and light-weight; (iv) reliable; structurally-sound; and durable. And, as explained above, be functional, hence, components which are not important/functional should-be-eliminated.

Moreover, the-device should-be: Efficient (in reducing food-cross-contamination); Functional (easilymaintained, user-friendly); Pleasant, in-appearance (suitable size and shape, attractive-design, good finishing); Durable (not easily-broken, stable, and robust-design, strong sound-structure); and Safe (harmless to the-user, noside-effects, and environmentally-friendly). To-achieve these-criteria, structurally, all-the-components should: (a) be symmetrical (and have polar-geometry-mark), if possible, as this also-helps in-manufacturing; (b) have consistency, in the-dimensions, used for feeding, orientation, and location; and (c) have location-points ( see Starovoytova, 2019a for more-details).

Lastly, the-following-account will try to-justify the-decision, made by the-design-team, that oneadditional-board (for poultry-raw-meat), is necessary. While numerous-potential-vehicles of food-borntransmission-exist, poultry-meat has-been identified as one of the-most-important food-vehicles for the-foodborne-diseases (Silva et al., 2011; FAO \& WHO, 2009). Salmonellosis and Campylobacteriosis are among themost-frequently-reported food-borne-diseases, worldwide (Bollaerts et al., 2008), and Enteritidis is the-mainserotype responsible-for human-infections (Moore et al., 2007; Pang et al., 2007; Oliveira et al., 2006). Accordingto Shu-Kee et al. (2015), Salmonellosis accounts for 93.8 million-food-borne-illnesses, and 155,000 deaths, peryear. Although only $20-40 \%$ of the-food-borne-diseases-cases are associated-with chicken-meat, consumption of chicken is still the-predominating-factor for Campylobacteriosis (Humphrey et al., 2007). Illnesses via chickenmeat can occur either by undercooking or by cross-contamination.

From the-results of a-study by Adetunji \& Isola (2011), it can be concluded that the-cross-contamination, between raw and processed-foods, by-surface-contact is hazardous, because Salmonella can adhere to the-surface, and form a-bio-film, resulting in a-source of contamination. In-addition, a-relatively-recent-study revealed that two-thirds of consumers failed to-adequately-wash hands, after handling raw-chicken, nearly 30 percent failed towash, or change the-cutting-board, after cutting raw-chicken, and one-third failed to-wash, or change a-knife, used to-cut raw-chicken-meat, before cutting raw-vegetables (WHO, 2006; 2002).

Salmonella pathogen - is a rod-shaped, Gram-negative facultative-anaerobe, which belongs to the-family Enterobacteriaceae (Barlow \& Hall, 2002). To-date, over 2500 Salmonella serotypes have-been-identified, and more-than-half of them belong to Salmonella enterica subsp.enterica, which accounts for the-majority of Salmonella infections in-humans. In-human-infections, the-four different-clinical-manifestations are: (i) enteric-fever, (ii) gastroenteritis, (iii) bacteraemia, and other-extraintestinal-complications, and (iv) chroniccarrier-state (Sheorey \& Darby, 2008). Salmonella infection contributes to the-economic-burden of both; industrialized and developing-countries, through the-costs, associated-with surveillance, prevention, and treatment of the-disease (Majowicz et al., 2010; Crump et al. 2004).

The-four-design-alternatives, gnerated by the-design-team, are shown in Figure 8.

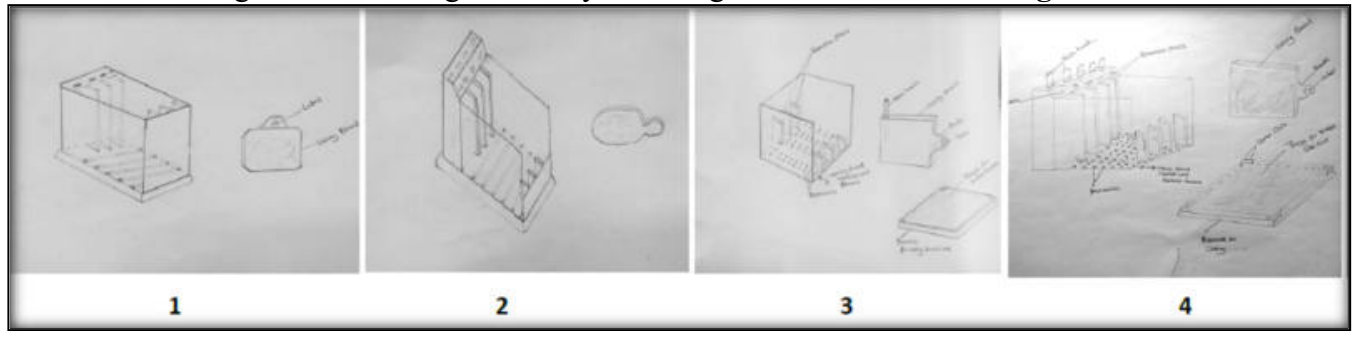

Figure 8: Hand-sketched four-design-alternatives.

3.5. Selection of the-best-design-alternative.

Alternative design \# 4 was selected, via standard-EDWM, with the-highest-score of 0.82 ; while Alternative \# 1 scored 0.53; Alternative \# 2-- 0.47, and Alternative \# $3-0.65$.

3.6. Description of the best-design-alternative, including its 2D-drawing and 3D-modeling.

Regarding the-dimensions of the-set, the-cutting-board-size acts as the-primary-determinant of the-sizes of othercomponents of the-designed-set; board-dimensions ( $\mathrm{L} \mathrm{x} \mathrm{B} \mathrm{x} \mathrm{T)} \mathrm{of} 30 \mathrm{~cm} \times 20 \mathrm{~cm} \times 10 \mathrm{~mm}$ were chosen (as one of the-most-common-board-sizes, currently used, worldwide). 
Figure 9 shows two-dimensional-drawing of the-main elements of the-set, with sizes; Figure 10 demonstrates the-set-assembly of the-best-alternative-design, while Figure 11 shows colour-corded-boards and the-position of labels; Figure 12 and Figure 13 show labels/symbols and dimensions of the-set-components, respectively.

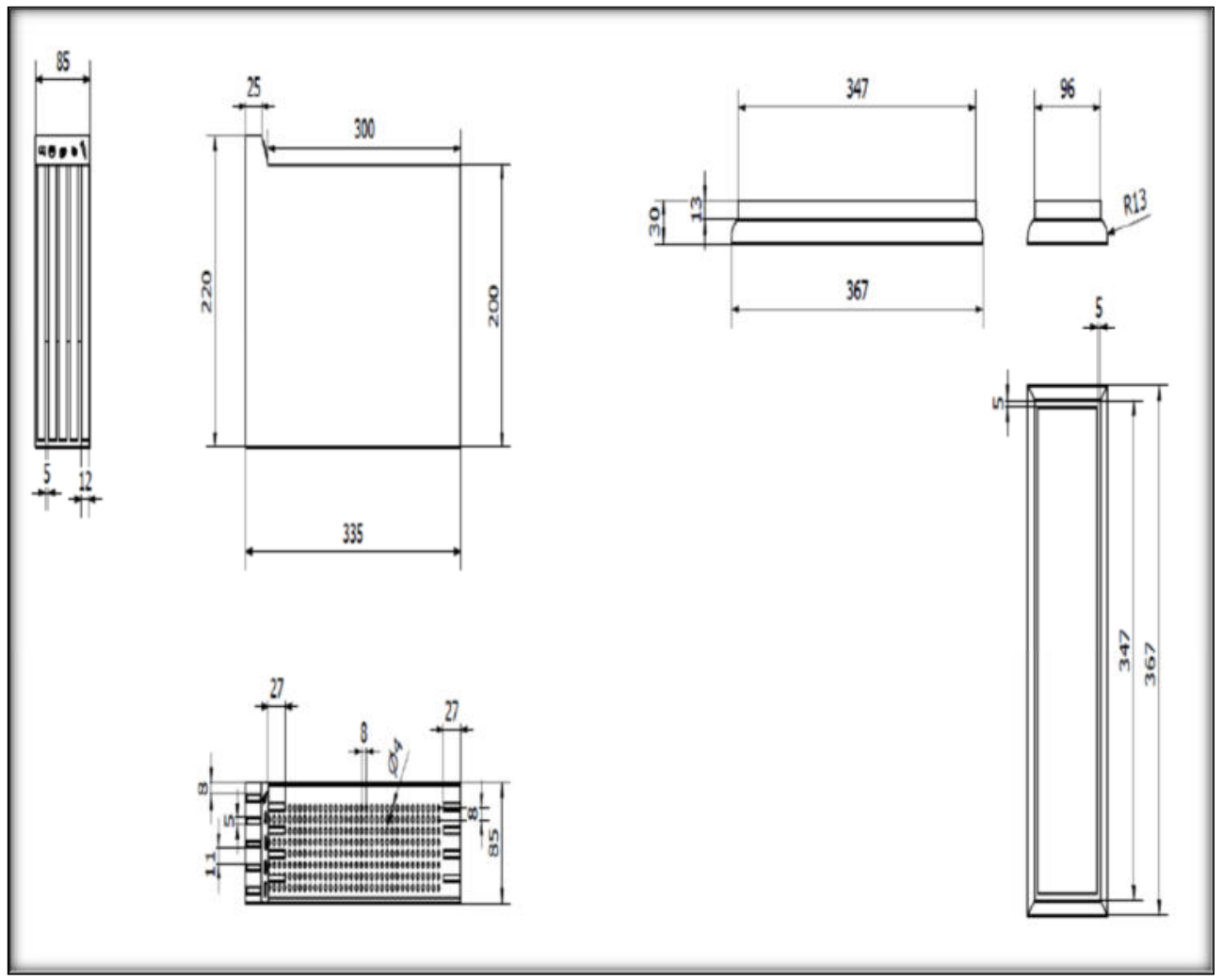

Figure 9: 2D drawings of the-main-elements of the-design-set.

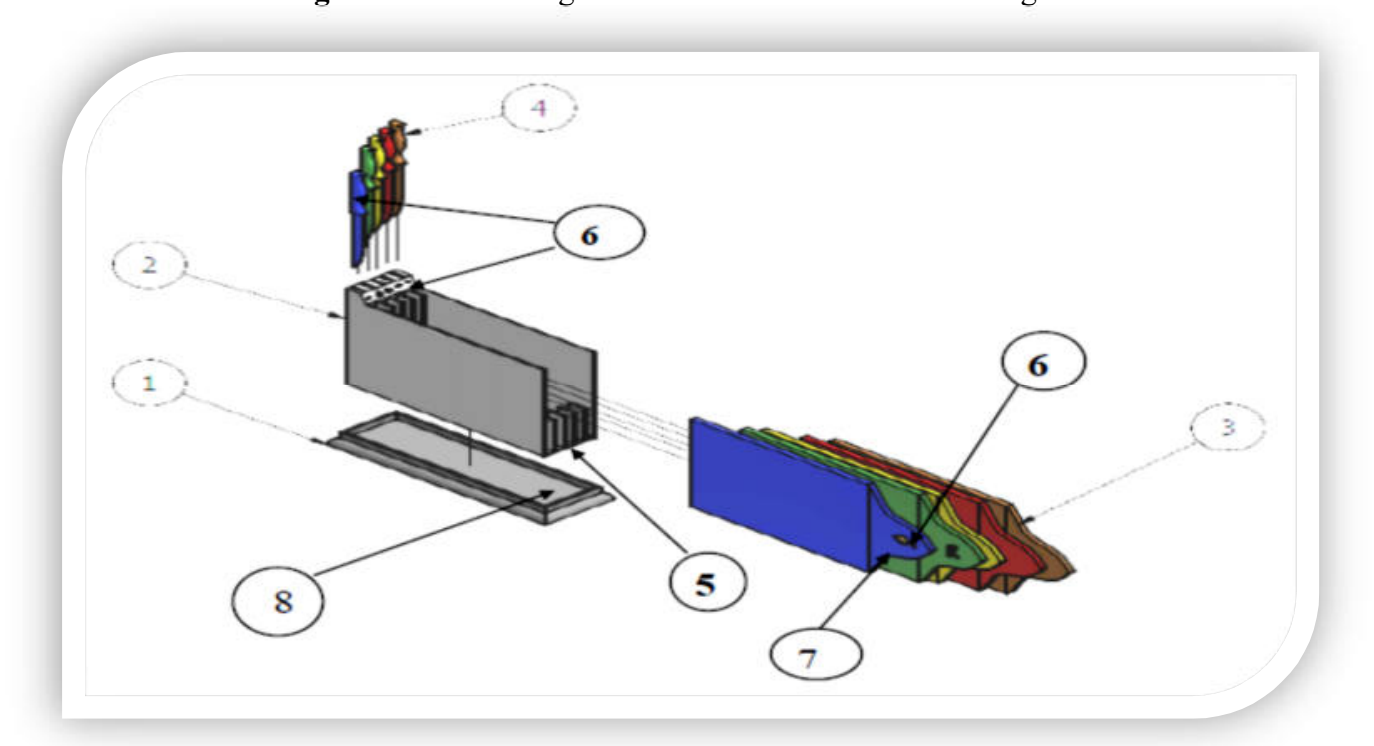

Figure 10: Set-assembly of the-best-alternative-design.

Keys: 1 - Basement; 2 - Stand; 3 - Boards (five); 4 - Knifes (five); 5 - Separation-plates; 6 - Labels/symbols; 7 - Handle of the-board; 8 -Perforations (see Figure 13 for details) 
Labels (positioned on each-board and each-knife, as-well-as on the-set itself, as an-inclined-panel) were introduced, to-cater for the-people with color-blindness (according to-the-fundamental-principles of theUniversal-design), and also to-avoid-confusion (as a-reminder which board is which, to all-users).

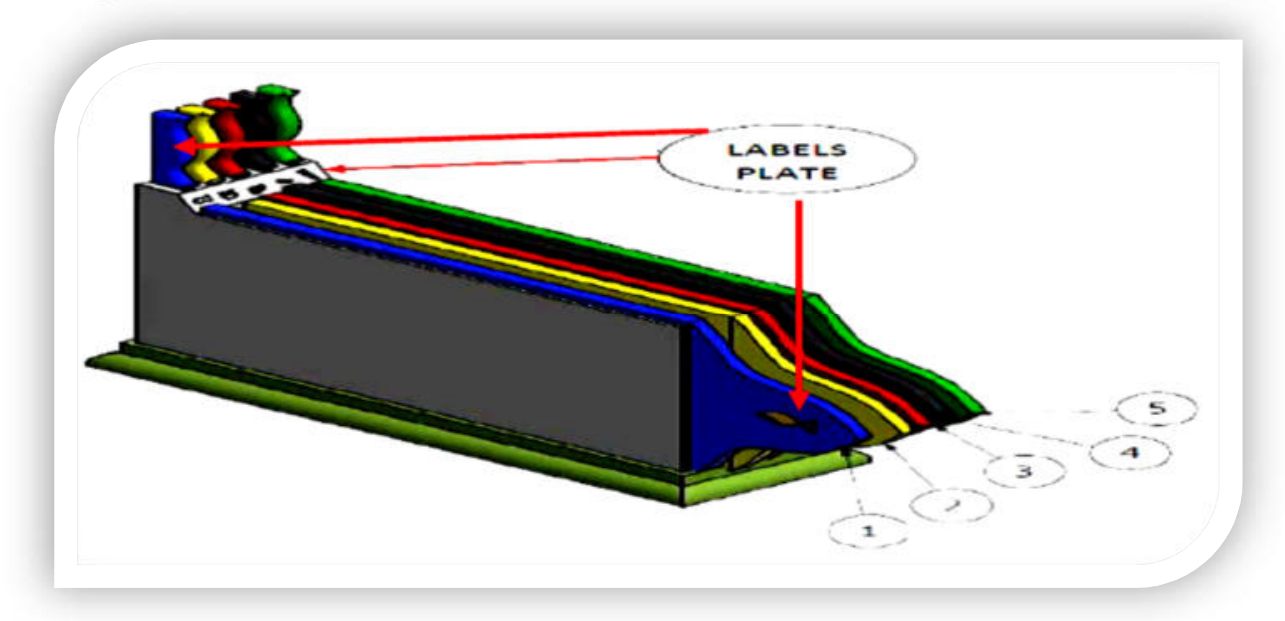

Figure 11: Color-corded-boards and the-position of labels.

1 - Blue (raw sea-food); 2 - Green (raw fruits and vegetables); 3 - Yellow (raw-poultry); 4 - Red (raw meat); 5 - Brawn (cooked food).

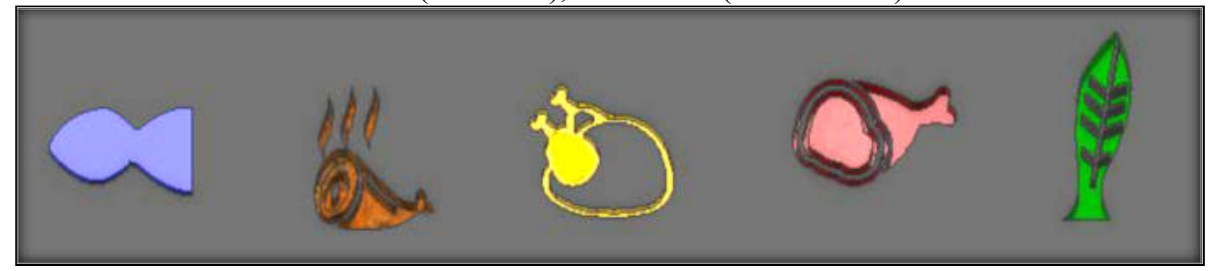

Figure 12: Labels/symbols.

Keys (left to right): Blue (for Raw-Fish); Brown (for Cooked-food); Yellow (for Raw-poultry); Red (for Raw-meat); and Green (for Raw-fruits and vegetables).

\subsection{Materials-selection.}

The-engineering-materials of mechanical and structural-engineering fall-into the-broad classes/families (Asby, 2010; 2005), such-as: (i) Metals (the-metals and alloys); (ii) Polymers (the-thermoplastics and thermo-sets); (iii) Elastomers (engineering-rubbers, natural and synthetic); (iv) Ceramics, technical-ceramics (Fine-ceramics capable of load-bearing-application), and Ceramics, non-technical (porous-ceramics of construction); (v) Glasses; and (vi) Hybrids (hybrids: composites; hybrids: foams; and hybrids: natural-materials).

According-to Ashby (2004), the-very-first-consideration, in-materials-selection, is on the-functionality of the-material; the-main-goal here is being-able to-produce products that function effectively, safely, and atacceptable-cost. The-functionality relates three-aspects, namely: (i) the-function of design-component (what it does), (ii) its-objective (intended-achievement), and (iii) constraints (limits to performance). In-this-study, thefunction of cutting-board is to-aid in-food-chopping-operations, with main-objective being elimination/reduction of food-cross-contamination. The-most-essential (and hence important)-constraint, in the-initial-consideration of materials-selection, in-this-study, is the-ability of a-material to-be-able to-be-dyed/colored in five-solid-colors (socalled 'color-coding'). Besides, a-knife-edge is a-delicate-structure, and can easily-be-blunted by a-surface, which is too-abrasive. A-good-cutting-board-material, hence, should be-relatively-soft, easy to-clean, and non-abrasive, but not fragile, to the-point of being-destroyed. A-good-cutting-board-material should be also less-porous, toprevent moisture-absorption, which facilitate bacteria thrive and cracks. Other-constraints include manufacturability, cost, porosity, health and safety-issues, etc. 


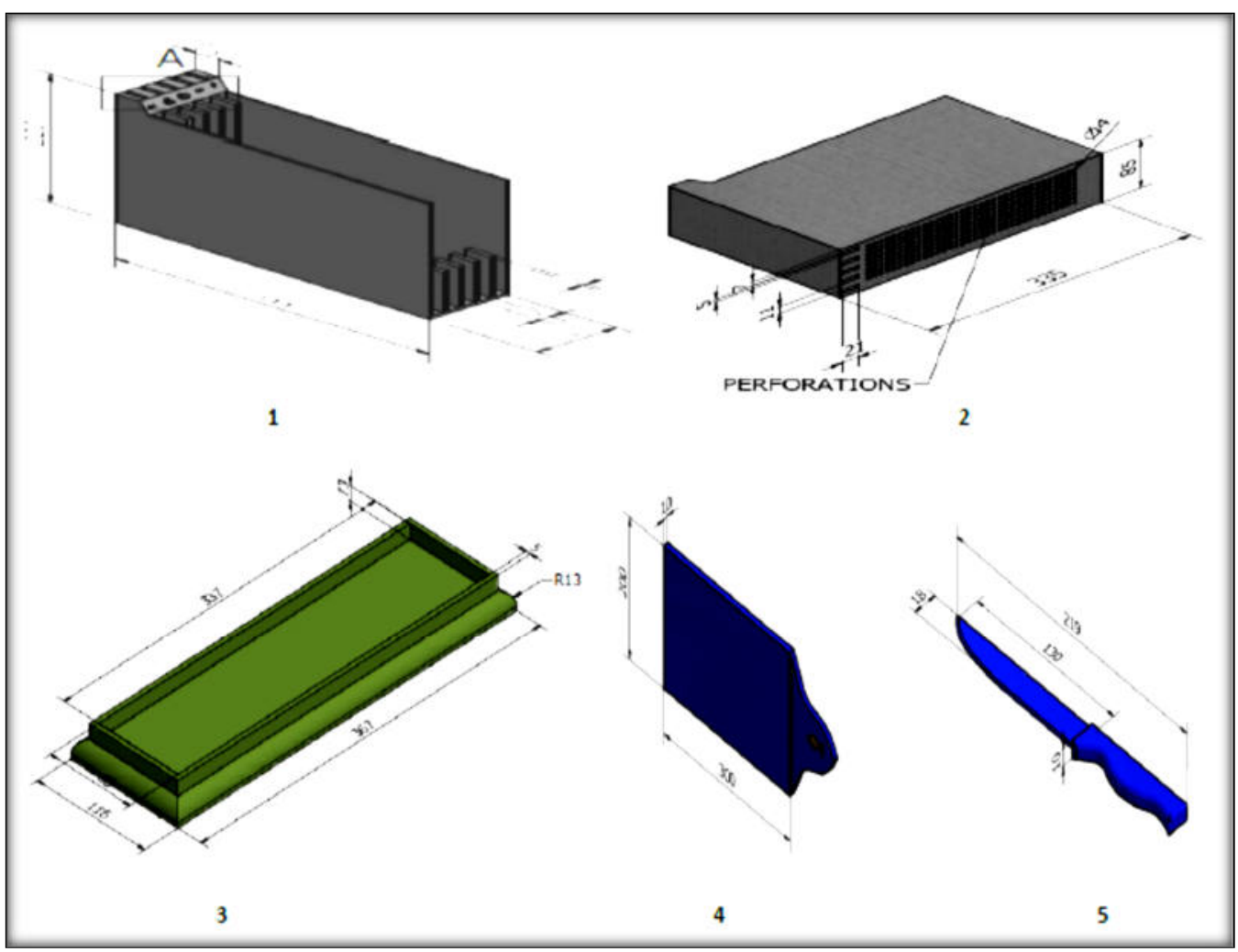

Figure 13: Dimensions of the-set-components.

Keys: 1 - Stand; 2 - Perforations in the-basement; 3 - Basement; 4 - Board; 5 - Knife.

This-study adopted so-called 'screening'-approach to materials-selection, where (Dobrzanski, 2001) elimination of materials starts by comparing their-attributes and limits, set by constraints, hence, if limits are not met, the-material is eliminated. Only 2 material-suitable-groups of materials were pre-selected, namely: (i) Polymers/'plastic; and (ii) Hybrids: Composites. Afterwards, the-composites-group was eliminated, due-to-lack of composites-manufacturing-equipment and expertise, in-Kenya, leaving the-group of polymer/plastics uncontested.

It-is important to-note, however, that there are over 60 materials in the 'polymer/plastic' group. Figure 14 shows a-comparative-property-chart, for selected-plastic-materials. The-main-properties for comparison, used here, are: cost (should be as-minimum-as possible), moisture-absorption (low), and tensile-strength (high).

From the-chart, it can be observed that polyethylene-materials are superior, based on-cost and moistureabsorption-properties; however, it-is not a-clear-cut, as they are of lower-tensile-strength. The-polyethylenematerials were selected, for further-screening; their-background-information follows.

Polyethylene or polythene (abbreviated PE; IUPAC name polyethene or poly(methylene)) is the-mostcommon-plastic. As of 2017, over 100 million tons of polyethylene-resins are produced, annually, accounting for $34 \%$ of the-total-plastics-market. Polyethylene is classified by its-density and branching. Its-mechanical-properties depend-significantly-on variables, such-as: the-extent and type of branching, the-crystal-structure, and themolecular-weight. There are several-types of polyethylene (Kurtz, 2015): (i) Ultra-high-molecular-weight polyethylene (UHMWPE); (ii) Ultra-low-molecular-weight polyethylene (ULMWPE or PE-WAX); (iii) Highmolecular-weight polyethylene (HMWPE); (iv) High-density polyethylene (HDPE); (v) High-density cross-linked polyethylene (HDXLPE); (vi) Cross-linked polyethylene (PEX or XLPE); (vii) Medium-density polyethylene (MDPE); (viii) Linear low-density polyethylene (LLDPE); (ix) Low-density polyethylene (LDPE); (x) Very-lowdensity polyethylene (VLDPE); and (xi) Chlorinated polyethylene (CPE). 


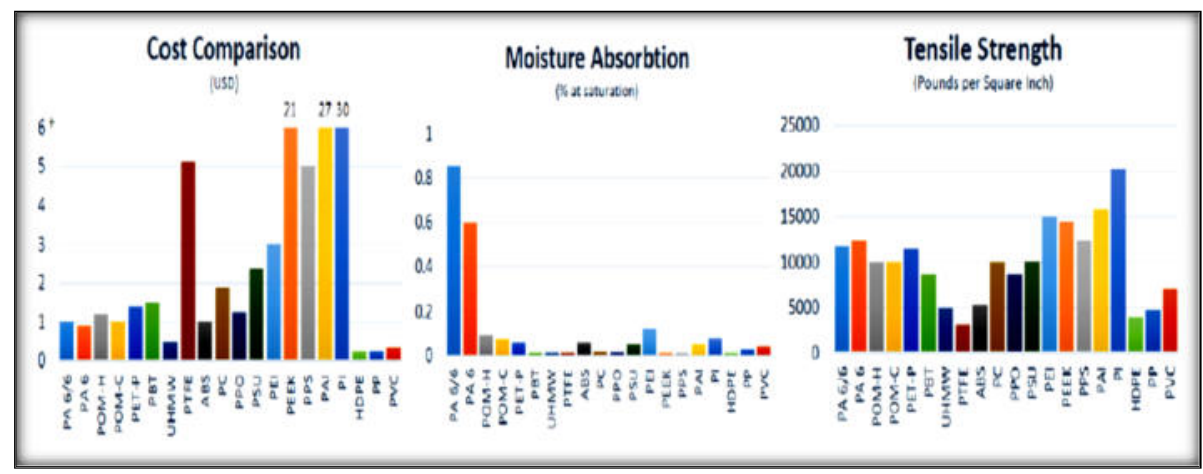

Figure 14: Plastics-polymers

Keys: (Precision Punch \& Plastics manufacturing-company, U.S.A.)

\begin{tabular}{|c|c|}
\hline PA $6 / 6$ & Extruded Nylon \\
\hline . PA 6 & Cast Nylon \\
\hline POM-H & Acetal Homopolymer (Delrin \\
\hline PON-C & Acetal Copolymer \\
\hline PET-P & Polyester PET-P \\
\hline PBT & Polyester PBT (Valox ${ }^{*}$ ) \\
\hline
\end{tabular}

\begin{tabular}{l} 
UHMW UHMW Polyethylene \\
\hline PTFE Teflon* \\
\hline ABS ABS \\
\hline PC Polycarbonate \\
\hline PPO Noryl॰ \\
\hline PSU Polysulfone \\
\hline PEItem* \\
PEER PEEK
\end{tabular}

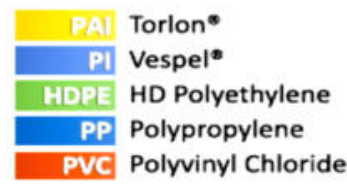

PE is usually a-mixture of similar-polymers of ethylene, with various-values of $n$. Polyethylene is athermoplastic; however, it can become a-thermo-set-plastic, when modified (such as cross-linked-polyethylene). Polyethylene is of low-strength, hardness and rigidity, but has a-high-ductility and impact-strength, as-well-as lowfriction. It shows strong-creep, under persistent-force, which can be reduced by addition of short-fibers. It feels waxy, when touched. The commercial applicability of polyethylene is limited by its-comparably low-melting-point. Higher-crystalinity increases density and mechanical and chemical-stability. Polyethylene absorbs almost no water. The-gas and water-vapor-permeability (only polar-gases) is lower than for most-plastics. In-particular, selecteddata/properties for PE, are: Chemical-formula - $\left(\mathrm{C}_{2} \mathrm{H}_{4}\right)_{\mathrm{n}}$; Density - 0.88-0.96 g/cm; Melting-point - $115-135^{\circ} \mathrm{C}$ $\left(239-275^{\circ} \mathrm{F} ; 388-408 \mathrm{~K}\right) ; \log P-1.02620$ (data are given for materials in their-standard-state (at $25^{\circ} \mathrm{C}\left[77^{\circ} \mathrm{F}\right]$, $100 \mathrm{kPa})$ (Geyer, 2017; Kurtz, 2015; Batra, 2014).

Considering that there are 11 types of polyethylene; the-study recommends to further-investigating which polyethylene-type is the-most-appropriate for this-particular design-set.

\section{Discussion.}

As-mentioned-earlier, a-substantial-proportion of food-borne-diseases has been-linked-to poor-food-preparation and hygienic-practices, in-the-home (Redmond \& Griffith, 2003). Cutting-boards are recognized as-possiblesources of cross-contamination, with pathogens, as-well-as spoilage-bacteria (Cliver, 2006; Carpentier, 1997). Bacteria may grow, or survive, for a-long-time on cutting-boards, which may subsequently be a-source for contamination of ready-to-eat-foods (Todd et al., 2009). Surveys show inadequate-handling of cutting-boards (lack-of or insufficient-cleaning) for 30-90\% of consumers (Redmond \& Griffith, 2003). Common-cleaningprocedures, used by consumers, at home, may not be sufficient to-completely remove pathogens from contaminated-cutting-boards (Cogan et al., 2002). According-to the-Food-Protection-Trends (2004), bacteria, on a-cutting-board, can double, after 10 minutes of use, whether cutting raw-meat or vegetables. The-discrepancy, between knowledge and practices, shows that consumer-education is not enough, to-prevent unsafe-practices, and has provided a-market for products with claimed-antimicrobial-activity (Aider, 2010; Marambio-Jones \& Hoek, 2010; Monteiro et al., 2009; Moretro et al., 2011; 2010; 2006). The-global-antimicrobial-compounds (AMCs)market is estimated-to-be worth USD 3 billion, and projected to-grow to USD 4.5 billion, and 590 kilotons, by 2020 (Grand View Research, 2013). Commercially-available-AMCs can-be-divided (Rosenberg et al., 2019) into: (i) powder-coatings, which can be electro-statically-layered to various-surfaces, and (ii) surface-modificationcoatings, that interact-with application-surface and confer-protection against-pathogens. They can be applied-to surfaces via spraying, draw-down-method, thin-film-coating, and spin-coating (Grand View Research, 2013).

In-recent-years, antimicrobial-polymers and coatings have-gained-interest, from both; academia-research and as industrial-products, due-to their-potential to-provide higher-quality-life and safety. Antimicrobial and antibacterial-agents are materials, capable of killing pathogenic-microorganisms. Surface-modification that 
effectively kills microbes, on-contact, without releasing a-biocide, represents a-modern and efficient-approach, toward continuous and permanent-sterile-materials. The-undesirable-growth of microorganisms, on-solid-surfaces, that is, bio-fouling, or bio-contamination of surfaces, represents an-important-threat in-diverse-surface-settings, for-example, medical-implants (Hetrick \& Schoenfisch, 2006); water-purification (Nguyen et al., 2012); or foodstorage and preparation (Hannon et al., 2017). Substances and food-contact-materials are antimicrobial-materials, if they realize "a reduction of Colony Forming Units (CFU) > 2-log"(Moerman, 2013).

The-antimicrobial-compound may be-incorporated throughout the-materials, or added, as a-coating, on the-surface of the-material. The-antimicrobial-agents can be of organic and inorganic-origin.

Inorganic antimicrobial-agents, including: (i) Silver - containing antimicrobial-materials (e.g., Silverions; Silver-bearing stainless-steel; and Silver-nano-particles); (ii) Copper - containing antimicrobial-materials (e.g., Copper-ions, Metallic-copper, Copper-alloys, Copper-bearing stainless-steel, Copper oxide nano-particles); (iii) Zinc - containing antimicrobial-materials (e.g., Zinc-ions, Zinc-oxide nano-particles); and (iv) Titanium containing antimicrobial-materials (e.g., Titanium, Titanium-dioxide, Titanium-dioxide nano-particles).

Organic antimicrobial-agents include: Triclosan N-halamine containing surfaces; Quaternary ammonium-compounds immobilized on surfaces; Organosilane quaternary ammonium-compounds; and Nalkylated-polyethyleneimines.

For-more-details, on each, of the-listed-above-agents, see Moerman (2013).

Hydrogels is the-most-important-family of hydrophilic-adhesion-resistant-coatings. $A$ hydrogel is athree-dimensional (3D) network of hydrophilic-polymers that can swell in-water, and hold a-large-amount of water, while maintaining the-structure, due-to chemical or physical-cross-linking of individual-polymer-chains. By definition, water must constitute at-least $10 \%$ of the-total-weight (or volume) for a-material to-be a-hydrogel (Bahram et al., nd; Wichterle \& Lím, 1960). There are four-major-categories of polymers and coatings, such-as (Baghdachi et al., 2015): (i) polymeric-coatings, with QA-groups; (ii) polymers with quaternary-phosphoniumgroups; (iii) norfloxacin containing-polymers; and (iv) polymeric-N-Halamines-group.

Besides, Triclosan is considered for a-polymer-additive, with-multiple-properties, to-be an-antimicrobial, with additional-benefits, as a-non-polar toughening-agent, and a-hydrophobic-wetting-agent (Petersen, 2016). Triclosan, 2, 4, 4'-trichloro-2' - hydroxydiphenyl-ether, has broad-spectrum-antimicrobial-effect, acting through multiple-mechanisms at high-concentrations, while inhibiting fatty-acid-synthesis at sub-lethal-concentrations (Jones et al., 2000; Levy et al., 1999). It has broad-spectrum-activity at low-concentrations, to-inhibit-both; grampositive and gram-negative-bacteria, and also different-virus and fungus (SCCS, 2010; CSC, 2001). Triclosan has been used-as an-antimicrobial-agent for almost 50 years, clinically and in-consumer-products, such-as cosmetics, toothpaste, and plastics. Triclosan has multiple-bacterial-target-sites for damage, depending on concentrations. Triclosan is bacterio-static to-prevent microbes from growing at low-concentrations, by inhibiting an-enzyme, involved in-fatty-acid-synthesis. On the-other-hand, triclosan is bactericidal, to-kill microbes, directly, at-higherconcentrations, by destabilizing bacterial-membranes, and also by-introducing intercalating-defects into abacterial-membrane. It can be incorporated by-mixing-into a-resin-system, before cure, melt-mixed with thermoplastic-polymers, which set on-cooling, into-a-solid, or alternatively applied as a-coating, through severaldifferent-methods (Petersen, 2014; NICNAS, 2009; Villalán et al., 2001).

In-general, the-antibacterial-products are marketed as an-improved-hygiene-barrier. There is growingconcern, however, regarding increased-use of products, containing antimicrobial-compounds, especially in thedomestic-sector. One of the-reasons, behind the-concern, is fear of development of antimicrobial-resistance (Aiello et al., 2007; Gilbert \& McBain, 2001, 2003; Levy, 2001), which is yet to-be-confirmed.

Furthermore, the-results, of this-unfunded concise-study (of preliminary-nature), are largely- relativelypositive, providing a-good-starting-point, for further and much-deeper-study, on the-same. Next-logical-step, would be a-detailed-design, which can-be-generated, using 3D-solid-modeling CAD-programs, such-as SolidWorks. Additionally, according to Ui et al. (2002), the-emphasis of the-design-decisions, unavoidably shiftsaway from technology, towards the-user-interaction-aspects, to-cope with the-new-appreciations of consumers, for the-aesthetic-values of materials. Several-studies, investigated the-relation, between materials and userinteraction-qualities, of products, and how users appraise materials. Selected-studies also-try to-classify the-visual and touch-dimensions of different-materials (see Smith et al., 2008) and, even, the-sound-dimensions, while in operation (see Ui et al., 2002).

Moreover, the-current (conceptual)-design is rather-uncomplicated, hence, EDWDM was considered tobe sufficient, during selection of the-best-design-alternative. At a-later (detail-design-stage) additional-methods, such-as: PuCC; AHP (Analytic-Hierarchy-Process); and TRIZ (Theory of Inventive-Problem-Solving) should-beapplied (see Starovoytova, 2019a; 2019b; Renzi et al., 2017; Starovoytova, 2016; 2015; Starovoytova et al., 2015, Mansor et al., 2014; 2013).

After selecting the-most-appropriate-material, the-further-studies should also-select the-appropriateprocess, to-manufacture the-final-set. A-process is a-method of shaping, finishing, or joining a- material. Themanufacturing-processes of Engineering fall-into nine-broad-classes; process-classes (Asby, 2010; Ashby \& 
Cebon, 2007) are: (i) Casting (sand, gravity, pressure, die, etc.); (ii) Pressure molding (direct, transfer, injection, etc.); (iii) Deformation processes (rolling, forging, drawing, etc.); (iv) Powder methods (slip cast, sinter, hot press, hip); (v) Special methods (CVD, electroform, lay-up, etc.); (vi) Machining (cut, turn, drill, mill, grind, etc.); (vii) Heat treatment (quench, temper, solution treat, age, etc.); (viii) Joining (bolt, rivet, weld, braze, adhesives); and (ix) Surface finish (polish, plate, anodize, paint). The-following-matrixes and charts by Asby (2010) can be used, to-select most-appropriate-process: (a) The-Process-Material matrix; (b) The-Process-Shape matrix; (c) TheProcess-Mass-range chart; (d) The-Process-Section-thickness chart; (e) The-Process-Tolerance chart; (f) TheProcess-Surface-roughness chart; and (g) The-Process-Economic-batch-size chart.

\section{Conclusion and Recommendations.}

Poor-hygiene, during preparation and/or consumption of food, in-conjunction-with the-ability of food-bornepathogens to-survive (for a-long-time), and also to-multiply, rapidly, can-lead-to food-cross-contamination. Foodcross-contamination, in-turn, can-lead-to food-born-diseases, resulting in-some-cases, in: (a) severe-sickness, or even death (either immediately, or shortly, after food-consumption), or (b) in-increased-risk of chronic-diseases (e.g., Guillan-Barre-syndrome, or rheumatoid-arthritis (CAST)).

This-study has accomplished all-its-objectives, by re-designing the-PRD and incorporating siximportant-upgrading, to-reduce food-cross-contamination, in the-new-product-design. The-study, however, was purely conceptual in-nature; and, hence, it is further-recommends to: (1) carry-out a-detailed-design (by incorporating the-user-interaction-aspects and using more-advanced-methods, such-as PuCC; AHP, and TRIZ, inselection of the-best-design-alternative); (2) select a-specific-material (out of the-group, identified by this-study, via Ashby-charts and matrixes); (3) choose a-mode of fabrication of the-set; (4) examine the-possibility of incorporating of AMCs; (5) fabricate the-prototype(s); (6) conduct explorative-use-ability-trial(s); and (7) analyze the-marketing-aspect of the-final-set.

This-work is potentially-beneficial-to engineering-product-design students and faculty, as-well-as to households and food-establishments (subject-to successful-implementation).

\section{Acknowledgement.}

The-author wishes to-acknowledge Kepha Dickson and Yassin Keya, for their-commitment and valuablecontribution to-the-completion and success of this-concise-project, particularly during the-design-stage.

\section{References.}

Abrishami, S.; Tall, B.; Bruursema, T.; Epstein, P. and Shah, D. (1994). "Bacterial Adherence and Viability on Cutting Board Surfaces”. [Online] Available: https://doi.org/10.1111/j.1745-4565.1994.tb00591.x $\left(12^{\text {th }}\right.$ August, 2018).

Abuga, M.; Nyamari, J. and Njagi. J. (2017). "Consumer Food Hygiene and Safety Practices in the Households in Langata Sub-County, Nairobi County, Kenya”, International Journal of Scientific and Research Publications, Vol. 7(5). ISSN 2250-3153.

ADA (2010). Americans with Disabilities Act. [Online] Available: http://www.ada.gov (12 ${ }^{\text {th }}$ August, 2018).

Adetunji, V. and Isola, T. (2011). Crystal Violet Binding Assay for Assessment of Biofilm Formation by Listeria monocytogenes and Listeria spp on Wood, Steel and Glass Surfaces, Global Veterinaria, 6(1).

ADPHID (2017). Avoid Food Cross-Contamination; Alabama Department of Public Health Infectious Diseases \& Outbreaks Division. [Online] Available: www.alabamapublichealth.gov/infectiousdiseases $\left(12^{\text {th }}\right.$ August, 2018).

Aider, M. (2010). "Chitosan application for active bio-based films production and potential in the food industry: review", Lwt-Food Science and Technology, 43.

Aiello, A.; Larson, E. and Levy, S. (2007). “Consumer antibacterial soaps: effective or just risky?”, Clinical Infectious Diseases, 45.

Ak, N.; Cliver, O. and Kaspar, C. (1994). "Cutting boards of plastic and wood contaminated experimentally with bacteria", J. Food Prot., 57.

Ashby, M. (2010). Material and Process Selection Charts. Ces Edupack. [Online] Available: www.grantadesign.com/education/(12 $12^{\text {th }}$ August, 2018).

Ashby, M. and Cebon, D. (2007). Teaching Engineering Materials: the CES EduPack Engineering Department, Cambridge University, England.

Ashby, M. and Johnson, K. (2002). Materials and Design: The Art And Science Of Material Selection In Product Design. Butterworth-Heinemann, Oxford.

Ashby, M. (1999). Materials Selection in Mechanical Design. Butterworth-Heinemann, Oxford, Second edition. Ashby, M. and Johnson, K. (2003). "The art of materials selection", Materials Today, December issue.

Ashby, M. (2005). Materials Selection in Mechanical Design; $3^{\text {rd }}$ Edition, Elsevier Butterworth-Heinemann Publications, U.K, ISBN 0750661682. 
Aviat, F.; Gerhards, C.; Rodriguez-Jerez, J.; Michel, V.; et al. (2016). "Microbial Safety of Wood in Contact with Food: A Review", Comprehensive Reviews in Food Science and Food Safety, 15 (3). DOI: 10.1111/1541-4337.12199.

Autodesk Inventor (2016). Professional-edition.

Baghdachi, J.; Qinhua Xu, Q. and Wu, L. (2015). Chapter 10: “Antibacterial Polymers and Coatings', [Online] Available: https://doi.org/10.1002/9781118883051.ch10. (12 ${ }^{\text {th }}$ August, 2018).

Bahram, M.; Mohseni, N. and Moghtader, M. (nd). An Introduction to Hydrogels and Some Recent Applications. [Online] Available: http://dx.doi.org/10.5772/64301. (12 $2^{\text {th }}$ August, 2018).

Ball, B.; Wilcock, A. and Aung, M. (2013). "Background Factors Affecting the Implementation of Food Safety Management Systems", Food Protection Trends, 30(2).

Barker, J.; Naeeni, M. and Bloomfield, S. (2003). "The effects of cleaning and disinfection in reducing Salmonella contamination in a laboratory model kitchen”, Journal of Applied Microbiology, 95.

Barlow, M. and Hall, B. (2002). "Origin and evolution of the AmpC beta-lactamases of Citrobacter freundii", Antimicrob Agents Chemother, 46. DOI: 10.1128/AAC.46.5.1190-1198.

Batra, K. (2014). Role of Additives in Linear Low Density Polyethylene (LLDPE) Films.

- $\quad$ Blom, J. (2009). A Dictionary of Hallucinations. Springer. ISBN 978-1-4419-1222-0.

Bloomfield, S. and Nath, K. (2013). Home Hygiene in Developing Countries Prevention of Infection in the Home and the Peri-Domestic Setting. International Scientific Forum on Home Hygiene - published 2006, updated 2013.

Bollaerts, K.; Aerts, M.; Faes, C.; Grijspeerdt, K.; Dewulf, J. and Mintiens, K. (2008). "Human salmonellosis: estimation of dose-illness from outbreak data, Risk Analysis, 28.

Bowe, F. (2000). Universal design in education. Westport, CT: Bergin and Gavey.

Budynas-Nisbet, F. (2008). Shigley's Mechanical Engineering Design (8th edition), McGraw-Hill's. ISBN 0390-76487-6.

Carpentier, B. (1997). "Sanitary quality of meat chopping board surfaces: a bibliographical study", Food Microbiology, 14.

CDC (2013). "Centers for Disease Control and Prevention: Surveillance for food-borne disease outbreaksUnited States, 2009-2010", Morb Mortal Wkly Rep, 62. [Online] Available: http://www.cdc.gov/mmwr/preview/mmwrhtml/mm6203a1.htm. (21 August, 2018).

CDC (2014). Centers for Disease Control and Prevention Surveillance for food-borne disease outbreaksUnited States, 2012: annual report. Centers for Disease Control and Prevention, Atlanta, GA. [Online] Available: http://www.cdc.gov/foodsafety/pdfs/foodborne-disease-outbreaks-annual-report-2012508c.pdf. (15 August, 2018).

CDC (2015). Centers for Disease Control and Prevention: Surveillance for food-borne disease outbreaksUnited States, 2013: annual report. Centers for Disease Control and Prevention, Atlanta, GA. [Online] Available: http://www.cdc.gov/foodsafety/pdfs/foodborne-disease-outbreaks-annual-report-2013508c.pdf. (3 August, 2018).

Chen, Y.; Jackson, K.; Chea, F. and Schaffner, D. (2000). "Quantification and variability analysis of bacterial cross contamination rates in common foodservice tasks", J Food Prot, 64.

Chen, Y.; Jackson, K.; Chea, F. and Schaffner, D. (2001). "Quantification and variability analysis of bacterial cross-contamination rates in common food service tasks", J Food Prot, 64.

Chan, X.; Goh, S. and Tan, N. (2014). "Subjects with color vision deficiency in the community: what do primary care physicians need to know?”, Asia Pacific Family Medicine, 13 (1); DOI: 10.1186/s12930-014-0010$\underline{3}$.

Cliver, D. (2006). "Cutting boards in Salmonella cross-contamination", Journal of AOAC International, 89.

Cogan, T.; Bloomfield, S. and Humphrey, T. (1999). "The effectiveness of hygiene procedures for prevention of cross-contamination from chicken carcasses in the domestic kitchen", Letters in Applied Microbiology, 29.

Cogan, T.; Slader, J.; Bloomfield, S. and Humphrey, T. (2002). "Achieving hygiene in the domestic kitchen: the effectiveness of commonly used cleaning procedures", Journal of Applied Microbiology, 92.

Crump, J.; Luby, S. and Mintz, A. (ed.) (2004). "The global burden of typhoid fever", Bulletin of the World Health Organization, 82.

CSC (2001). Ciba Specialty Chemicals: Antimicrobials Irgasan DP 300 Irgacare MP Irgacide LP 10. General information on chemical, physical and microbiological properties. Brochure 2520 Ciba Specialty Chemical Corporation, High Point, NC 27265Pub. No. AgB2520e.02.2001. Edited in Switzerland.

D’Souza, D.; Sair, A.; Williams, K.; Papafragkou, E.; Jean, J.; Moore, C. and Jaykus, L. (2006). "Persistence of caliciviruses on environmental surfaces and their transfer to food", Int J Food Microbiol., 108. [Online] Available: http://dx.doi.org/10.1016/j.ijfoodmicro.2005.10.024. (11 August, 2018).

Danford, G. (2003). "Universal design: People with vision, hearing, and mobility impairments evaluate a model 
building", Generations, 27(1).

Dawson, P.; Han, I.; Cox, M.; Black, C. and Simmons, L. (2007). "Residence time and food contact time effects on transfer of Salmonella Typhimurium from tile, wood, and carpet: testing the five-second rule", $J$ Appl Microbiol, 102.

de Jong, A.; Verhoeff-Bakkenes, L.; Nauta, M. and de Jong, R. (2008). "Cross-contamination in the kitchen: effect of hygiene measures", Journal of Applied Microbiology, 105.

Dobrzanski, L. (2001). Materials' design as an important element of engineering design of machines and their parts. Proceedings of the XII ADM International Conference. September 5th-7th 2001. Rimini, Italy.

Donlan, R. (2002). "Biofilms: microbial life on surfaces", Emerg Infect Dis, 8. [Online] Available: http://dx.doi.org/10.3201/eid0809.020063. (26 August, 2018).

Doordan, D. (2003). "On Materials", Design Issues, 19.

EIZO (2006).”Color Universal Design Handbook”. Tokyo: Color Universal Design Organization. [Online] Available: http://www.iar.unicamp.br/lab/luz/ld/Cor/Color\%20Universal\%20Design\%20handbook.pdf (12 ${ }^{\text {th }}$ August, 2018).

Erickson, W. and Lee, C. (2003). Disability statistics in the United States. [Online] Available: http://www.disabilitystatistics.org. (12 ${ }^{\text {th }}$ August, 2018).

Erlandson, R. (2008). Universal and accessible design for products, services, and processes. Boca Raton, FL: CRC Press.

FAO \& UN (1999). Food and Agriculture Organization of the United Nations: "The Importance of Food Quality and Safety for Developing Countries". Committee on World Food Security, $25^{\text {th }}$ Session, Rome, May 31-June3, 1999. [Online] Available: http://www.fao.org/docrep/meeting/x 1845e.htm. (12 ${ }^{\text {th }}$ August, 2018).

FAO \& WHO (2005). Regional Conference on Food Safety for Africa (the conference), held in Harare, Zimbabwe from 3 to 6 October, 2005. [Online] Available: http://www.fao.org/3/a0215e/A0215E20.htm. (12 ${ }^{\text {th }}$ August, 2018).

FAO and WHO (2009). "Salmonella and Campylobacter in chicken meat", Microbiological Risk Assessment Series, 19.

FAO (2017). Food and Agriculture Organization of the United Nations: Food Handlers Manual. Washington, DC: PAHO.

Food Protection Trends (2004). "Use of Microbial Modeling and Monte Carlo Simulation to Determine Microbial Performance Criteria on Plastic Cutting Boards in Use in Foodservice Kitchens", Food Protection Trends, Vol. 24(1).

Frank, J. (2001). "Microbial attachment to food and food contact surfaces", Advances in Food and Nutrition Research, Vol. 43; ISSN 1043-4526, ISBN 9780120164431.

FSWSG (2008). Food Service Workers Safety Guide. [Online] Available: http://www.ccohs.ca/products/publications/food.html (2 August, 2018).

Gachuki, K. (2012). Food Handling Practices and the Prevalence of Food-borne Pathogens among Food Handlers in Embu Municipality, Kenya. Kenyatta University Institutional Repository.

Gilbert, P. and McBain, A. (2003). "Potential impact of increased use of biocides in consumer products on prevalence of antibiotic resistance", Clinical Microbiology Reviews, 16.

Gilbert, P. and McBain, A. (2001). "Biocide usage in the domestic setting and concern about antibacterial and antibiotic resistance", Journal of Infection, 43.

Geyer, R.; Jambeck, J. and Law, K. (2017). "Production, use, and fate of all plastics ever made", Science Advances, 3 (7). DOI:10.1126/sciadv.1700782; PMC 5517107; PMID 28776036.

Gkana, E.; Lianou, A. and Nychas, G. (2016). "Transfer of Salmonella enterica Serovar Typhimurium from Beef to Tomato through Kitchen Equipment and the Efficacy of Intermediate Decontamination Procedures", Journal of Food Protection, Vol. 79(7).

Goodman, J.; Dong, H.; Langdon, P. and Clarkson, P. (2006). Factors involved in industry's response to inclusive design. In P. J. Clarkson, P. Langdon, \& P. Robinson (Eds.). Designing accessible technology. London: Springer-Verlag.

Gordon, B. (September 20, 2018). 4 Simple Steps to Keep Food Safe. [Online] Available: https://www.eatright.org/homefoodsafety/four-steps/separate/separate---the-basics. (12 ${ }^{\text {th }}$ August, 2018).

Gordon, N. (1998). “Color blindness”, Public health, 112 (2); DOI10.1038/sj.ph.1900446. PMID 9581449.

Gorman, R.; Bloomfield, S. and Adley, C. (2002), "A study of cross-contamination of food-borne pathogens in the domestic kitchen in the Republic of Ireland", International Journal of Food Microbiology, Vol. 76.

Gould, L.; Walsh, K.; Vieira, A.; Herman, K.; Williams, I.; Hall, A. and Cole, D. (2013). "Surveillance for foodborne disease outbreaks-United States, 1998-2008", MMWRSurveill Summ, 62. [Online] Available: http://www.cdc.gov/mmwr/preview/mmwrhtml/ss6202a1.htm. ( $1^{\text {st }}$ August, 2018).

Gould, L.; Walsh, K.; Vieira, A.; Herman, K.; Williams, I.; Hall, A. and Cole, D. (2010). Surveillance for food- 
borne disease outbreaks - United States, 1998-2008. Centers for Disease Control and Prevention.

Grand View Research (2013). Antimicrobial coatings market analysis and segment forecasts to 2020. [Online] Available: https://www.grandviewresearch.com/ (1 August, 2018).

Hannon, J.; Kerry, J.; Cruz-Romero, M.; Azlin-Hasim, S.; Morris, M. and Cummins, E. (2017). "Kinetic desorption models for the release of nano-silver from an experimental nano-silver coating on polystyrene food packaging", Innovative Food Science \& Emerging Technologies, 44; DOI 10.1016/j.ifset.2017.07.001.

Harrison, G.; Tanner, J.; Pilbeam, D. and Baker, P. (1988). Human Biology. Oxford: Oxford University Press. ISBN 978-0-19-854144-8.

Hayden, M.; Bonten, M.; Blom, D.; Lyle, E.; van de Vijver, D. and Weinstein, R. (2006). "Reduction in acquisition of vancomycin-resistant enterococcus after enforcement of routine environmental cleaning measures", Clinical Infectious Diseases, 42.

Hetrick, E. and Schoenfisch, M. (2006). "Reducing implant-related infections: active release strategies", Chemical Society Reviews, 35(9); DOI 10.1039/b515219b.

Hewer, S. (Ed.). (1995). The DAN teaching pack: Incorporating age-related issues into design courses. London: RSA.

HHMI (2006). Howard Hughes Medical Institute: A Practical Guide to Scientific Management for Post-docs and New Faculty. [Online] Available: https://www.hhmi.org/sites/default/files/Educational\%20Materials/Lab\%20Management/Making\%20th e\%20Right $\% 20$ Moves/moves 2 ch8.pdf (12 ${ }^{\text {th }}$ August, 2018).

Hilton, A. and Austin, E. (2000), "The kitchen dishcloth as a source of, and vehicle for, Food-borne pathogens in a domestic setting", International Journal of Environmental Health Research, Vol. 10.

Hoffman, P. (2008). "Accommodating Color Blindness" (PDF).

Humphrey, T.; O’Brien, S. and Madsen, M. (2007). "Campylobacters as zoonotic pathogens: a food production perspective", Int J Food Microbiol, 117.

Jensen, D.; Friedrich, L.; Harris, L.; Danyluk, M. and Schaffner, D. (2013). "Quantifying transfer rates of Salmonella and Escherichia coli O157:H7 between fresh-cut produce and common kitchen surfaces", $J$ Food Prot, 76. [Online] Available: http://dx.doi.org/10.4315/0362-028X.JFP-13-098. (1 August, 2018).

Jones, R.; Jampani, H.; Newman, J. and Lee, A. (2000). “Triclosan: A review of effectiveness and safety in health care settings", American Journal of Infection Control, 28.

Juvinall, R. and Marshek, K. (2012). Fundamentals of Machine Component Design. 5th edition, John Wiley \& Sons, Inc., USA, ISBN-13 9781118012895.

Kemmeren, J.; Mangen, M.; van Duynhoven, Y. and Havelaar, A. (2006). Priority Setting in Food Borne Pathogens No. 330080001/2006. Bilthoven: National Institute for Public Health and the Environment (RIVM).

Kennedy, J.; Blair, I.; McDowell, D. and Bolton, D. (2005). "The microbiological status of non/food contact surfaces in domestic kitchens and the growth of Staphylococcus aureus in domestic refrigerators", Food Protection Trends, 25.

Kolvin, J. and Roberts, D. (1982). "Studies on the growth of Vibrio cholerae biotype El Tor and biotype classical in foods", J. Hyg. Camb., 89.

Kramer, A.; Schwebke, I. and Kampf, G. (2006). "How long do nosocomial pathogens persist on inanimate surfaces? A systematic review", 3BMC Infectious Diseases, 6.

Kumiko, T.; Yuko, C.; Dao, T.; Nguyen, C.; Krishna, C. and Masamine, J. (2009). "Survey of Food Hygiene Practices at Home and Childhood Diarrhoea in Hanoi, Viet Nam”, Journal of Health Population Nutrition, 602-611.

Kurtz, S. (2015). UHMWPE Biomaterials Handbook. Ultra-High Molecular Weight Polyethylene in Total Joint Replacement and Medical Devices (3 ${ }^{\text {rd }}$ Ed.). Elsevier. DOI:10.1016/C2013-0-160837; ISBN 9780323354356.

Kusumaningrum, H.; vanAsselt, E.; Beumer, R.and Zwietering, M. (2004). "A quantitative analysis of crosscontamination of Salmonella and Campylobacter spp. via domestic kitchen surfaces", J Food Prot, 67.

Kusumaningrum, H.; Riboldi, G.; Hazeleger, W. and Beumer, R. (2003). "Survival of foodborne pathogens on stainless steel surfaces and crosscontamination to foods", Int J Food Microbiol, 85. [Online] Available: http://dx.doi.org/10.1016/S0168-1605(02)00540-8. (14 August, 2018).

Larson, A. (2016). "Is Color-Blindness a Disability for Employment Under the ADA", ExpertLaw.

Levy, C.; Roujeinikova, A.; Sedelnikova, S.; Baker, J.; Stuitje, A.; Slabas, A.; Rice, D. and Rafferty, J. (1999). "Molecular basis for triclosan activity", Nature, 398.

Levy, S. (2001). “Antibacterial household products: cause for concern”, Emerging Infectious Diseases, 7.

Luber, P. (2009). "Cross-contamination versus undercooking of poultry meat or eggs which risks need to be managed first?”, International Journal of Food Microbiology, 134. 
Majowicz, S.; Musto, J.; Scallan, E.; Angulo, F.; Kirk, M.; O'Brien, S.; Jones, T.; Fazil, A. and Hoekstra, R. (2010). "The global burden of nontyphoidal Salmonella gastroenteritis", Clinical Infectious Diseases, 50(6). DOI: 10.1086/650733.

Mansor, M.; Sapuan, E.; Zainudin, A.; et al. (2013). "Hybrid Natural and Glass Fibers Reinforced Polymer Composites Material Selection Using Analytical Hierarchy Process for Automotive Brake Lever Design", Materials and Design, 51.

Mansor, M.; Sapuan, E.; Zainudin, A.; et al. (2014). "Conceptual Design of Kenaf Fiber Polymer Composite Automotive Parking Brake Lever Using Integrated TRIZ-Morphological Chart-Analytic Hierarchy Process Method", Materials and Design, 54.

Marambio-Jones, C. and Hoek, E. (2010). "A review of the antibacterial effects of silver nano-materials and potential implications for human health and the environment", Journal of Nanoparticle Research, 12.

Maule, A. (2000). "Survival of verocyto-toxigenic Escherichia coli O157 in soil, water and on surfaces", Symposium Series (Society for Applied Microbiology, 29.

McAdams, D. and Kostovich, V. (2011). "A framework and representation for universal product design”, International Journal of Design, 5(1).

McIntyre, D. (2002). Colour blindness: causes and effects. Chester: Dalton Publishing. ISBN 978-0-9541886-03. OCLC 49204679.

Medeiros, L.; Kendall, P.; Hillers, V.; Chen, G. and Dimascola, S. (2001). "Identification and classification of consumer food-handling behaviors for food safety education", J Am Diet Assoc, 101.

Midelet, G. and Carpentier, B. (2002). "Transfer of microorganisms, including Listeria monocytogenes, from various materials to beef", Appl Environ Microbiol, 68. [Online] Available: http://dx.doi.org/10.1128/AEM.68.8.4015-4024.2002. (28 August, 2018).

Milling, A.; Kehr, R.; Wulf, A. and Smalla,K. (2005). "Survival of bacteria on wood and plastic particles: Dependence on wood species and environmental conditions”, Holzforschung, 59(1); DOI: 10.1515/HF.2005.012; ISSN 1437-434X.

Miranda, R. and Schaffner, D. (2016). "Longer contact times increase cross-contamination of Enterobacter aerogenes from surfaces to food", Appl Environ Microbiol, 82; DOI:10.1128/AEM.01838-16.

Moerman, F. (2013). “Antimicrobial Materials, Coatings And Biomimetic Surfaces With Modified Microtography To Control Microbial Fouling Of Product Contact Surfaces Within Food Processing Equipment: Legislation, Requirements, Effectiveness And Challenges", Journal of Hygienic Engineering and Design, 1. UDC 664.013.8:614.31.

Monteiro, D.; Gorup, L.; Takamiya, A.; Ruvollo, A.; Camargo, E. and Barbosa, D. (2009). "The growing importance of materials that prevent microbial adhesion: antimicrobial effect of medical devices containing silver", International Journal of Antimicrobial Agents, 34.

Montville, R.; Chen, Y. and Schaffner, D. (2001). "Glove barriers to bacterial cross-contamination between hands to food", J Food Prot, 64.

Moore, G.; Blair, I. and McDowell, D. (2007). "Recovery and transfer of Salmonella Typhimurium from four different domestic food contact surfaces", Journal of Food Protection, 70.

Moore, C.; Sheldon, B. and Jaykus, L. (2003). "Transfer of Salmonella and Campylobacter from stainless steel to romaine lettuce", J Food Prot, 66.

Møretrø, T.; Heir, E.; Mo, K.; Habimana, O.; Abdelgani, A. and Langsrud, S. (2010). "Factors affecting survival of Shigatoxin-producing Escherichia coli on abiotic surfaces", International Journal of Food Microbiology, 138.

Møretrø, T.; Sonerud, T.; Mangelrød, E. and Langsrud, S. (2006). "Evaluation of the antimicrobial effect of a triclosan-containing industrial floor used in the food industry", Journal of Food Protection, 69.

Møretrø, T.; Høiby-Pettersen, G.; Habimana, O.; Heir, E. and Langsrud, S.(2011). "Assessment of the antibacterial activity of a triclosan-containing cutting board", International Journal of Food Microbiology, 146.

Mukhola, S.M. (2000). Factors Influencing the Safety and Quality of Street Food in Rural Areas. Pretoria: Technikon Pretoria.

Mylius, S.; Nauta, M. and Havelaar, A. (2007). "Cross-contamination during food preparation: a mechanistic model applied to chicken-borne Campylobacter", Risk Anal, 27.

Nauta, M.; Jacobs-Reitsma, W. and Havelaar, A. (2007). "A risk assessment model for Campylobacter in broiler meat", Risk Anal, 27.

Neely, A. and Maley, M. (2000). "Survival of enterococci and staphylococci on hospital fabric and plastic", Journal of Clinical Microbiology, 38.

NEI (2015). "Facts About Color Blindness".

Neitz, M. (2007). "Severity of Colorblindness Varies", Medical College of Wisconsin.

Nguyen, T.; Roddick, F. and Fan, L. (2012). "Bio-fouling of water treatment membranes: a review of the 
underlying causes, monitoring techniques and control measures", Membranes, 2(4); DOI 10.3390/membranes2040804.

NICNAS (2009). Australian Government, Department of Health and Ageing: National Industrial Chemical Notification and Assessment Scheme, Sydney Australia. 2009. Priority Existing Chemical Assessment Report No. 30, Triclosan. [Online] Available: http://www.nicnas.gov.au/publications/car/pec/ pec30/pec 30 full report pdf.pdf $\left(12^{\text {th }}\right.$ August, 2018).

Noyce, J.; Michels, H. and Keevil, C. (2006). "Potential use of copper surfaces to reduce survival of epidemic meticillin-resistant Staphylococcus aureus in the healthcare environment", Journal of Hospital Infection, 63.

Oliveira, K.; Oliveira, T.; Teixeira, P.; Azeredo, J.; Henriques, M. and Oliveira, R. (2006). "Comparison of the adhesion ability of different Salmonella Enteritidis serotypes to materials used in kitchens", Journal of Food Protection, 69, 2352e2356.

Pang, J.; Chiu, T.; Helmuth, R.; Schroeter, A.; Guerra, B. and Tsen, H. (2007). “A pulsed field gel electrophoresis (PFGE) study that suggests a major world-wide clone of Salmonella enterica serovar Enteritidis", International. Journal of Food Microbiology, 116.

Parry, S.; Slader, J.; Humphrey, T.; Holmes, B.; Guildea, Z.; Palmer, S. (2005). “A case-control study of domestic kitchen microbiology and sporadic Salmonella infection”, Epidemiology and Infection, 133.

Peloquin, A. (1994). Barrier-free residential design. New York: McGraw-Hill.

Petersen, R. (2014). "Computational conformational antimicrobial analysis developing mechano-molecular theory for polymer Biomaterials in Materials Science and Engineering”, Int J Comp Mat Sci Eng., 3.

Petersen, R. (2016). "Triclosan antimicrobial polymers", AIMS Mol Sci., 3(1); DOI:10.3934/molsci.2016.1.88.

Popovic, T.; Olsvik, O.; Blake, P. and Wachsmuth, K. (1993). "Cholera in the Americas: Food-borne Aspects", Journal of Food Protection, Vol. 56 (9).

Preiser, W. and Ostroff, E. (Eds.). (2001). Universal design handbook. New York: McGraw-Hill.

Ravishankar, S.; Zhu, L. and Jaroni, D. (2010). "Assessing the cross contamination and transfer rates of Salmonella enterica from chicken to lettuce under different food-handling scenarios", Food Microbiology, 27.

Redmond, E. and Griffith, C. (2003). "Consumer food handling in the home: a review of food safety studies", $J$ Food Prot, 66.

Renzi, C.; Leali, F. and Di Angelo, L. (2017). "A review on decision-making methods in engineering design for the automotive industry", Journal of Engineering Design, 28:2; DOI: 10.1080/09544828.2016.1274720

Robine, E.; Boulangé-Petermann, L. and Derangère, D. (2002). "Assessing bactericidal properties of materials: the case of metallic surfaces in contact with air", J Microbiol Methods, 49. [Online] Available: http://dx.doi.org/10.1016/S0167-7012(01)00371-2. (11 August, 2018).

Roozenburg, N. and Eekels, J. (1995). Product Design: Fundamentals and Methods. West Sussex, UK: John Wiley \& Sons.

Rosenberg. M.; et al. (2019). "Potential eco-toxicological effects of antimicrobial surface coatings: a literature survey backed up by analysis of market reports", PeerJ, 2. DOI 10.7717/peerj.6315.

Ryu, J. and Beuchat, L. (2005). "Biofilm formation by Escherichia coli O157:H7 on stainless steel: effect of exopolysaccharide and curli production on its resistance to chlorine", Appl Environ Microbiol, 71.

Sampers, I.; Jacxsens, L.; Luning, P.; Marcelis, W.; Dumoulin, A and Uyttendaele, M. (2010). "Performance of food safety management systems in poultry meat preparation processing plants in relation to Campylobacter spp. Contamination", J Food Prot., 73(8).

Scallan, E.; Hoekstra, R.; Angulo, F.; Tauxe, R.; Widdowson, M.; Roy, S.; Jones, J. and Griffin, P. (2011). "Food-borne illness acquired in the United States-major pathogens", Emerg Infect Dis, 17. [Online] Available: http://dx.doi.org/10.3201/eid1701.P11101. (11 August, 2018).

SCCS (2010). European Commission, Scientific Committees on Consumer Safety: Opinion on Triclosan, Antimicrobial Resistance. Directorate-General for Health and Consumers, Opinion approved 7th Plenary. 2010. SCCP/1251/09. [Online] Available: http://ec.europa.eu/health/scientific_committees/ consumer safety/docs/sccs o 023.pdf (12 ${ }^{\text {th }}$ August, 2018).

Scott, E. and Bloomfield, S. (1990). "The survival and transfer of microbial contamination via cloths, hands and utensils", Journal of Applied Bacteriology, 68.

Scott, E. and Bloomfield, S. (1993). "An in-use study of the relationship between bacterial contamination of food preparation surfaces and cleaning cloths", Letters in Applied Microbiology, 16.

Sheorey, H. and Darby, J. (2008). "Searching for Salmonella", Australian Family Physician, 37.

Shevell, S. (2003). The Science of Color. Amsterdam: Elsevier. ISBN 978-0-444-51251-2. OCLC 52271315.

Shu-Kee, E.; Pusparajah, P.; Nurul-Syakima, A.; Hooi-Leng, S.; Kok-Gan, C. and Learn-Han, L. (2015). "Salmonella: A review on pathogenesis, epidemiology and antibiotic resistance", Frontiers in Life Science, 8:3, 284-293, DOI: 10.1080/21553769.2015.1051243 
Silva, J.; Leite, D.; Fernandes, M,; Mena, C.; Gibbs, P. and Teixeira, P. (2011). “Campylobacter spp. as a foodborne pathogen: a review", Frontiers in Microbiology, 2.

Simunovic, M. (2010). "Colour vision deficiency" (PDF), Eye, 4 (5); DOI:10.1038/eye.2009.251. PMID 19927164.

Sixty Materials in the 'Plastic' Group (see https://plastics.ulprospector.com/generics).

Soares, V.; Pereira, J.; Viana, G.; Izidoro, T.; et al. (2012). "Transfer of Salmonella Enteritidis to four types of surfaces after cleaning procedures and cross-contamination to tomatoes", Food Microbiology, $30453 \mathrm{e} 456$.

Spring, K.; Parry-Hill, M.; Fellers, T. and Davidson, M. (2007). "Human Vision and Color Perception”, Florida State University Archive.

Smith, S.; Alao, F.; Goodluck, E.; et al. (2008). "Prevalence of Salmonella typhi among food handlers from 'bukkas' in Nigeria", British Journal of Biomedical Science, 65:3; DOI: 10.1080/09674845.2008.11978119.

Starovoytova, D.; Namango, S.; Ataro, E.; Sitati, S.; Oyondi, E. and Tuigong, D. (2015). "Innovative Application of Android Smart-Phone for Identification of Selected Fabric Weave Designs", International Journal of Computer Technology \& Applications, Vol. 6 (2), ISSN 2229-6093.

Starovoytova, D. and Namango, S. (2016). "Innovative Conceptual Design of Manual-Concrete-Block-MakingMachine", Innovative Systems Design and Engineering; ISSN 2222-1727 (Paper) ISSN 2222-2871 (Online), Vol.7, No.7.

Starovoytova, D. and Njoroge, M. (2016). ” Design Simulation and Analysis of Manual Block-Making Machine", Innovative Systems Design and Engineering; ISSN 2222-1727 (Paper) ISSN 2222-2871 (Online), Vol.7, No.7.

Starovoytova, D. (2018). "Snoring and its-management (Part 1/2): A Review", Innovative Systems Design and Engineering, Vol. 9 (2); ISSN (Paper) 2222-1727, ISSN (Online) 2222-2871.

Starovoytova, D. (2017)." Hazards and Risks at Rotary Screen Printing (Part 6/6): Control of Chemical Hazards via Cleaner Production Approaches", Industrial Engineering Letters (U.S.A.), ISSN 2224-6096 (Paper); ISSN 2225-0581 (online), Vol.7, No.7.

Starovoytova, D. " Theory of inventive problem solving (TRIZ): his-story", IJISET - INTERNATIONAL, Journal of Innovative Science, Engineering \& Technology(U.S.A.), Vol. 2 Issue 7, July 2015, ISSN $2348-7968$.

Starovoytova, D.; Tuigong, D.; Sitati, S.; Namango, S. and Ataro, E. (2015). "Potential of Theory of Innovative Problem Solution (TRIZ) in Engineering Curricula", IJISET - INTERNATIONAL Journal of Innovative Science, Engineering \& Technology, Vol. 2 Issue 5. ISSN 2348 - 7968.

Starovoytova, D. (2019a). "Conceptual Design of a Massaging Device to Mitigate Exercise Associated Calf Muscle Cramps", Innovative Systems Design and Engineering, Vol.10, No.2, ISSN 2222-1727 (Paper) ISSN 2222-2871 (Online); DOI: 10.7176/ISDE.

Starovoytova, D. (2019b). Innovative Engineering Product Design: Concepts and Practical Examples. LAMBERT Academic Publisher, Germany, ISBN: 978-620-0-21999-2.

Stiles, W. and Wyszecki, G. (2000). Color science: concepts and methods, quantitative data and formulae. Chichester: John Wiley \& Sons. ISBN 978-0-471-39918-6. OCLC 799532137.

Todd, E.; Greig, J.; Bartleson, C.; Michaels, B. (2009). “Outbreaks where food workers have been implicated in the spread of foodborne disease. Part 6. Transmission and survival of pathogens in the food processing and preparation Environment", Journal of Food Protection, 72.

Ui, E.; Cho, G.; Na, Y. and Casali, J. (2002). “A fabric sound evaluation structure for totally auditory-sensible textiles", Textile Research Journal, July issue.

$\underline{\text { US }} 0195763 \mathrm{Al}$ (2002). By Benjamin.

US 0046301 A1 (2004). By Thompson et al.

US 19221 A1 (2004). By Davis.

US 0001359 A1 (2007). By Pearl et al.

US 0080487 A1 (2007). By YartZ.

US 0146353 A1 (2009). By Hashim.

US 200723 A1 8 (2009). By Lim et al.

US14814 A1 (2010). By Zeitlin.

US D605.908 S (2009). By Pearl et al.

US 7,681,871 B2 (2010). By Shew et al.

US D638,265 S 5 (2011). By Shamoon.

US 8,070,148 B2 (2011). By Nishida.

US D655,939 S (2012). By Tracy.

US 8.220,789 B2 (2012). By Pourounidis et al. 
US 9,155.427 B1 (2015). By Kumar.

van Asselt, E.; de Jong, A.; de Jonge, R. and Nauta, M. (2008). "Cross-contamination in the kitchen: estimation of transfer rates for cutting boards, hands and knives", Journal of Applied Microbiology, 105.

van Asselt, E.; Fischer, A.; de Jong, A.; Nauta, M. and de Jong, R. (2009). "Cooking practices in the kitchenobserved versus predicted behavior", Risk Analysis, 29.

Vanderheiden, G. (1997). The Principles Of Universal Design. [Online] Available: http://www.design.ncsu.edu/cud/about ud/udprincipleshtmlformat.html\#top. (12 ${ }^{\text {th }}$ August, 2018).

Velusamy, V.; Arshak, K. and Korostynska, O. (2010).” An overview of food-borne pathogen detection: In the perspective of biosensors', Biotechnology advances 28(2); DOI: 10.1016/j.biotechadv.2009.12.004

Villalán, J.; Mateo, C.; Aranda, F.; et al. (2001). "Membrano-tropic effects of the antibacterial agent triclosan", Arch Biochem Biophys, 390.

Wendt, C.; Dietze, B.; Dietz, E. and Rüden, H. (1997). "Survival of Acinetobacter baumannii on dry surfaces", $J$ Clin Microbiol, 35.

World Health Organization. (2006). Five Keys to Safer Food. [Online] Available: http://www.who.int/foodsafety/publications/consumer/manual keys.pdf (23 August, 2018).

World Health Organization. (2008). WHO Initiative to Estimate the Global Burden of Food-borne Diseases. Increasing Impact through Collaboration”, Food-borne Disease Stakeholders Meeting. Geneva. [Online] Available: http://www.who.int/foodsafety/foodborne_disease/FERG_Stakeholder_2008.pdf. (7 August, 2018).

WHO (2002). Food-borne diseases, emerging. Geneva, World Health Organization (Fact Sheet 124). [Online] Available: http://www.who.int/mediacentre/factsheets/fs124/en. (12 ${ }^{\text {th }}$ August, 2018).

WHO (2008). World Health Organization: Food-borne disease outbreaks: guidelines for investigation and control. ISBN 9789241547222.

World Bank. (2000). Food Safety Issues in the Developing World. Technical Paper No.469, Library of Congress.

World Health Organization. (1999). Basic Food Safety for Health Workers. Geneva.

World Health Organization. (2006). Five Keys to Safer Food. [Online] Available: http://www.who.int/foodsafety/publications/consumer/manual keys.pdf . (12 ${ }^{\text {th }}$ August, 2018).

World Health Organization. (2008). WHO Initiative to Estimate the Global Burden of Food-borne Diseases. Increasing Impact through Collaboration", Food-borne Disease Stakeholders Meeting. Geneva. [Online] Available: http://www.who.int/foodsafety/foodborne disease/FERG_Stakeholder_2008.pdf. (12 ${ }^{\text {th }}$ August, 2018).

WHO (2002). WHO global strategy for food safety. Geneva: World Health Organization.

WHO (2008). The 3 fives. Retrieved 2018 October, from World Health Organization. [Online] Available:http://www.who.int/foodsafety/areas work/food-hygiene/3 fives/en/. (12 ${ }^{\text {th }}$ August, 2018).

Wichterle, O. and Lím, D. (1960). "Hydrophilic Gels for Biological Use", Nature, 185; DOI: 10.1038/185117a0.

Wilks, S.; Michels, H. and Keevil, C. (2006). "Survival of Listeria monocytogenes Scott A on metal surfaces: implications for cross-contamination", Int J Food Microbiol, 111. [Online] Available: http://dx.doi.org/10.1016/j.ijfoodmicro.2006.04.037. (6 August, 2018).

Wilks, S.; Michels, H. and Keevil, C. (2005). "The survival of Escherichia coli O157 on a range of metal surfaces", Int J Food Microbiol, 105. [Online] Available: http://dx.doi.org/10.1016/j.ijfoodmicro.2005.04.021. (16 August, 2018).

Williams, A.; Avery, L.; Killham, K. and Jones, D. (2005). "Persistence of Escherichia coli O157 on farm surfaces under different environmental conditions", Journal of Applied Microbiology, 98.

Wong, B. (2011). "Color blindness", Nature Methods, 8(6): DOI:10.1038/nmeth.1618. PMID 21774112.

WHO (2014). Food Borne Disease Surveillance: Burden of Food Borne Diseases. [Online] Available: www.who.int/foodborne disease/burden/en/. (11 August, 2018).

World Bank (2000). Food Safety Issues in the Developing World. Technical paper No. 469.

Xi, L.; Qin, D.; An, X. and Wang, G. (2013). "Resistance of Natural Bamboo Fiber to Microorganisms and Factors that May Affect Such Resistance", Bio-Resources, 8 (4).

Zhang, S. (2014). "The Story Behind Syracuse's Upside-Down Traffic Light"; Gizmodo.

Zhao, P.; Zhao, T.; Doyle, M.; Rubino, J. and Meng, J. (1998). "Development of a model for evaluation of microbial cross-contamination in the kitchen", $J$ Food Prot, 61.

Zwietering, M. and van Asselt, E. (2005). The range of microbial risks in food processing. In Handbook of Hygiene Control in the Food Industry ed. Lelieveld, H.L.M., Mostert, M.A. and Holah, J. Cambridge: Woodhead Publishing Limited. 